\title{
Genuine Savings as a Test of New Zealand Weak Sustainability
}

\author{
Mubashir Qasim \\ Les Oxley \\ School of Accounting, Finance and Economics \\ University of Waikato \\ \& \\ Eoin McLaughlin \\ School of Geography \& Sustainable Development \\ University of St. Andrews
}

\begin{abstract}
The key aims of this paper are to: i) to extend the World Bank's (WB) measure of Genuine Savings (GS) for New Zealand by using a longer time-series of data, 1950 - 2015; ii) improve GS estimates for New Zealand by adding additional dimensions to GS i.e. forestry; iii) investigate the relationship between several GS measures and the discounted values of GDP per capita and consumption per capita, used to proxy well-being; iv) test a series of hypotheses which relate GS to the change in future well-being using the framework proposed by (Ferreira, Hamilton, \& Vincent, 2008) and v) investigate the effects of a growing population on the availability of future capital stocks by considering the consequences of 'wealth-dilution' as defined by Ferreira, et. al., (2008). The paper makes a contribution to the literature on GS, particularly in the context of New Zealand, by considering patterns of GS and well-being over a longer time span of data than has been previously used and adds to a relatively small, but growing literature on tests of GS using long- or relatively long- time series data (see e.g. Greasley, et. al., 2014; Greasley, et. al., 2017, Hanley, Oxley, Greasley, \& Blum 2016). We conclude, based on the data used here, that New Zealand's GS has been positive (i.e. weakly sustainable), since the start of our data series, even without allowing for the contribution of technological advancement. However, we also conclude that the effects of a growing population and a savingsgap, have lead to a 'wealth-dilution' effect needed to maintain real wealth per capita, as we estimate that there was an average savings gap (GS as a percentage of Gross National Savings) over the period $1955-2015$ of $0.5 \%$ per annum.
\end{abstract}

Keywords: Sustainability, Genuine Savings, Natural Capital, Hartwick Rule, New Zealand.

JEL classifications: Q01, Q25, Q56

Acknowledgements: The New Zealand Marsden Fund supported this research, for which we are appreciative. We wish to thank David Greasley, Matthias Blum and Nick Hanley for allowing us to use methods from our previously, published joint research and Tony Burton, Tim $\mathrm{Ng}$ (New Zealand Treasury), Adam Tipper (Statistics New Zealand) and Brett Longley (NZ Ministry of the Environment) for feedback, suggestions and support.

\section{Address for correspondence:}

Professor Les Oxley, School of Accounting, Finance and Economics, University of Waikato, Hamilton, New Zealand. Email: les.oxley@waikato.ac.nz 


\subsection{Introduction: Genuine Savings as an Indicator of Sustainable Development}

"Sustainability" is a concept that has attracted considerable attention over the year (see for example the bibliometric analysis by Qasim, 2017). Some of the ensuing discussions about whether countries are acting in a sustainable manner depend crucially on the specific notion(s) of sustainability that is/are being used, inferred or assumed.

The UN Sustainable Development Goals have brought the discussion of sustainable development to the attention of policy makers. One of the goals is the 'sustained, inclusive and sustainable economic growth'. Both the World Bank (2006, 2011, 2018) and the UNUIHDP and UNEP $(2012,2014)$ have been torchbearers in measuring sustainable economic development from the approach of comprehensive/inclusive wealth and changes in wealth as opposed to income (GDP). Genuine Savings (GS), also referred to as Adjusted Net Savings (ANS), Comprehensive Investment ( $\mathrm{Cl}$ ) and Inclusive Investment (II), has become one of the more commonly used indicators of sustainable development over the long-run (Arrow, Dasgupta, Goulder, Mumford, \& Oleson, 2012, Blum et al., 2017a, Greasley et al., 2014a, Hamilton \& Clemens, 1999, Pezzey, 2004) ${ }^{1}$. The most recent World Bank (2018) report highlights ANS trends across regions and publish summary tables by countries. However, given the widespread use of the GS indicator, legitimate tests of the approach have, until recently, been limited. The World Bank (2011, 2018), while updating wealth and ANS estimates, has not updated tests of this indicator since its 2005 Wealth of Nations report (World Bank 2006, chapter 6). The core contribution of this paper is to estimate Genuine Savings for New Zealand over the period 1950-2015. Given the quality and quantity of data available to measure NZ sustainability trends, New Zealand is surprisingly absent from these discussions - there is no mention of New Zealand in WB (2018). We will also add to the sparse empirical literature by applying the approach to tests of (weak) sustainability applied to New Zealand.

GS was first proposed by Pearce \& Atkinson (1993) as an indicator of 'weak sustainability', based on the Hartwick Rule (Hartwick, 1977, 1990) according to which income from the use of non-renewable resources should be reinvested in renewable resources in order to

\footnotetext{
${ }^{1}$ For a 'primer' and partial survey of this literature see Oxley, L. (2017).
} 
maintain total wealth and to achieve non-declining well-being over time. Following this framework, Pearce and Atkinson (Pearce \& Atkinson, 1993, Pearce, Markandya, \& Barbier, 1989) elaborated on the approach to suggest that an economy which saves more than the combined depreciation of its stocks of natural capital and produced capital will be (weakly) sustainable. Whenever GS takes negative values, it indicates that the economy is on an unsustainable (in terms of the Pearce et al. (1989), definitions) development path. According to Hamilton \& Atkinson (2006), if the total wealth (sum of all types of capital stocks i.e. human capital, produced capital and natural) is related to social welfare, whatever sustainability definition is used, it necessarily involves the creation and maintenance of total wealth. In other words, non-declining per capita total wealth has to be maintained intergenerationally to realise sustainability (Dasgupta \& Mäler, $2001^{2}$ ). Weak sustainability (WS), the underlying assumption of GS, shows how different types of capital are combined to produce a stream of total wealth over time (Hanley, Dupuy, \& McLaughlin, 2015). Pearce et al. (1989) noted the extent to which natural resource depletion can be compensated for by the equivalent investment in human capital or produced capital leading to two cases for this intergenerational rule:

1. Sustainable development requires non-declining total wealth (weak sustainability)

2. Sustainable development requires non-declining natural wealth (strong sustainability)

The concept of weak sustainability is embedded in the argument that natural capital and produced capital are substitutable. The notion of weak sustainability emerged in the 1970s (Dietz \& Neumayer, 2007) when neoclassical models of economic growth were extended to account for non-renewable natural capital as a factor of production (Dasgupta \& Heal, 1974, Hartwick, 1977, Solow, 1974). These aggregate economic growth models account for the optimal use of income produced from the non-renewable resource extraction in order to establish a rule by how much of it to consume and how much should be reinvested in produced (or other forms of) capital for future consumption. The key question posed by these models was whether the optimal growth is sustainable in the sense of non-declining well-being which proved to be implausible in a model which includes non-renewable

\footnotetext{
${ }^{2}$ See Fenichel, E.P., and Abbott, J.K. (2014). for recent developments of the Dasgupta/Maler approach.
} 
resource as a factor of production. It turns out that that consumption declines to zero in the long-run as a result of saving for optimal growth (Solow, 1974). It therefore becomes necessary to define rules for non-declining welfare over time based on the maintenance of natural capital, produced capital, human capital and social capital.

Hartwick (1977) developed a general rule that the rents produced from the depletion of the non-renewable resource should be reinvested in the produced capital. This could be considered as a general rule of weak sustainability where the rate of change of net capital investment, which includes gross investment in all types of capital, which is measurable and subtractable from depreciation or consumption, is not allowed to be become negative (Hamilton, 1994). Assuming substitutability between different types of capital stocks (i.e. produced, natural and human capital), GS measures year-on-year changes in total capital. A country is said to be sustainable if it maintains or increases the overall stocks of capital (Pearce \& Atkinson, 1993).

Hartwick's and Solow's models consider renewable and non-renewable resources within a Cobb-Douglas production function model which is characterized by a unitary and constant elasticity of substitution between all factors of production. In other words, it assumes that natural capital and produced capital are similar and substitutable. To validate this assumption, either of the following must hold: (i) natural resources are abundant; (ii) or the elasticity of substitution between natural capital and produced capital is equal to or great than unity; (iii) technological advancement can boost productivity of natural capital at a higher rate than its depletion (Dietz \& Neumayer, 2007). In order to measure weak sustainability, we need to associate economic values to the reduction in the quantity of natural capital and to environmental degradation i.e. the economic cost of damage to the quality of natural capital. This will enable planners to correctly understand if the natural capital losses are being compensated equivalently or not. Commonly used measures of weak sustainability are: environmentally-adjusted net product; genuine savings (GS); measures of resource depletion; measures of environmental degradation; the index of sustainable economic welfare etc. (Asheim, 1994, Dietz \& Neumayer, 2007, Pearce \& Atkinson, 1993, Quiggin, 1997, Romero \& Linares, 2014). Among these indicators, GS is a widely used 
indicator of sustainable development and long-term well-being with the World Bank publishing measures of GS for a panel of countries since 1970.

The key aims of this paper are to: i) to extend the World Bank's measure of GS for New Zealand by using longer time-series data - in our case the period 1950 - 2015; ii) improve GS estimates for New Zealand by adding the most relevant dimensions to GS i.e. forestry which is ignored in Work Bank's GS model; iii) investigate the relationship between several GS and discounted values of GDP per capita as a long-term well-being; iv) test a series of hypotheses which relate GS to the change in future well-being using the framework proposed by (Ferreira, Hamilton, \& Vincent, 2008) and v) investigate the effects of a growing population on the availability of future capital stocks by considering the consequences of 'wealthdilution' as defined by Ferreira, et. al., (2008). The paper makes a contribution to the literature on GS, particularly in the context of New Zealand, by considering patterns of GS and well-being over the relatively long-run compared to existing empirical studies which rely on much shorter time periods. The paper adds to a relatively small, but growing literature on tests of GS applied to countries in Oceania see for example, Brown et. al. (2005), to detailed country specific studies of GS (Pezzey et al. 2006; Ferreira \& Moro 2011; Mota \& Martins 2010) and in particular those using long- or relatively long- time series data (see e.g. Greasley, et. al. 2014; Greasley, et. al. 2017, Hanley, Oxley, Greasley, \& Blum 2016) which is required by the theory, yet frequently not undertaken in the literature which concentrates more on short time scale or panel-based estimation (see Ferreira, Hamilton, \& Vincent, 2008; Ferreira and Vincent, 2005).

The remainder of the paper is organized as follows. Section 2 describes the GS modelling framework, and the specific approach used in this paper. Section 3 describes the data used and their sources, and the range of specific models to be tested. Section 4 presents the empirical estimates including the results of undertaking the hypothesis tests defined in Sections 2 and 3. Finally, Section 5 provides a discussion of the results, some conclusions and suggestions for future research.

\subsection{The Theory of Genuine Savings and Future Wellbeing.}

The theoretical foundations of Genuine Savings are well-established, see Hanley et al (2015) for a review of the theoretical literature. In this study, we apply the theoretical framework of 
Hamilton \& Hartwick (2005a) using the empirical framework proposed by Ferreira et al. (2008), FHV hereafter.

The theoretical model (equation 1) shows how the future changes in well-being equals genuine savings:

$\int_{t}^{\infty} \frac{\mathrm{d} c(v)}{\mathrm{d} v} e^{\int_{t}^{v}-(p(\tau)-\gamma) d \tau}=g(t)$

Where $\mathrm{c}$ is per capita consumption, $\gamma$ is a constant population growth rate, $\rho$ is a consumption discount rate, and $\mathrm{g}$ is genuine savings. A key point regarding this model is that it is set in infinite time. FHV extended this framework by outlining $g$, Genuine savings, as:

$g=\dot{k}-F_{R} r-\gamma \omega$

Where $\dot{k}$ is the year on year change in capital per capita, $F_{R} r$ is the shadow value of natural capital extraction per capita and $\omega$ is wealth per capita. This relationship explains how GS is determined by the per capita net change in natural capital and produced capital (the first two terms on the right-hand side of equation (2) adjusted by a wealth "wealth dilution effect" from population growth $-\gamma \omega$. Equation (2) therefore shows the constituents of the measure of GS at any point in time.

The main theoretical relationship proposed by $\mathrm{FHV}$ is that in any period $t$, the value of $g$ should be equal to the present values of changes in per capita consumption, from time $t$ to infinity if the consumption discount rate $\rho$ is adjusted downwards by the constant population growth rate (Dasgupta, 2001). If population grows at a variable rate, then the relationship between GS and the discounted values of changes in per capita consumption is also changed.

In a competitive economy, the per capita rate of GS for country $i$ at time $t$ should be equal to the present value of future changes in per capita consumption adjusted for a term which

\footnotetext{
${ }^{3}$ Ferreira, Hamilton and Vincent (2008) present as their equation 1 (as above), the infinite horizon version of the Genuine Savings relationship. The fact that the theoretical version relates to an infinite horizon reinforces why, in empirical models, longer time series data are likely to generate results more closely aligned to the theoretical underpinnings than those from short time series or small T panels.
} 
shows the effects of population growth on per capita wealth - the "wealth dilution effect" with variable population growth rates.

\subsection{The approach taken in this paper}

We apply the FHV (2008) GS and future well-being framework proposed to the case of New Zealand. Our approach extends the World Bank work in a number of important ways.

Firstly, we use data from multiple resources in New Zealand, over an extended period of $1950-2015$, to more closely approximate or proxy the definitions of the variables in the theoretical model (i.e. the longer horizon relates more to the infinite time setting in equation 1).

Secondly, we examined the effect of time as an uncontrolled capital stock through exogenous technological progress (using a measure of total factor productivity (TFP), which expands the production possibilities of the economy (Pezzey, Hanley, Turner, \& Tinch, 2006)). One important contribution is that we matched time horizons applied to discount the TFP growth series with that of the dependent variable discussed in detail in the data section. In previous studies, this has been kept constant, for example, Pezzey et al. (2006), Greasley et al. (2014, 2017) and Blum, McLaughlin, \& Hanley (2017b) and set at 20 years or 30 years in Hanley et al. (2016).

Thirdly, we captured changes in human capital through investments in education. According to Hamilton (2006), the process of development can be characterised as economies converting their natural capital into the other forms of capital e.g. human capital and/or produced capital. Similarly, the importance of human capital for long-term development, is also acknowledged by Arrow et al. (2012). It is widely accepted that the investments in human capital development has direct impact on productivity (Black \& Lynch, 1996, Blundell et al., 1999, Gemmell, 1996) therefore many studies on economic growth has used expenditure on education as a proxy of human capital at national level. On the downside, however, this proxy might not capture individual's capacity to earn income, or capabilities to perform better at micro-level which has led to the development of alternative methods such as Sen's capability approach for individual level studies. 
Fourthly, we tested two alternative indicators of future well-being: (i) changes in the present value of per capita consumption as in FHV; and changes in per capita real GDP. Hypothesis tests are conducted which impose a range of restrictions.

In particular, based on FHV, the key hypothesis tests related to determine whether the theoretical relationship between GS and future well-being hold are:

$P V \Delta C_{i t}=\beta_{0}+\beta_{1} g_{i t}^{*}+\epsilon_{i t}$

Where all terms are the same as in equation (2) except that $g_{i t}^{*}$ includes both changes in human capital and the value of exogenous technological progress as part of the capital stocks together with changes in natural capital and produced capital. For a non-constant population growth rates and wealth dilution effect, the related theoretical relationship becomes:

$P V \Delta C_{i t}+P V\left(\Delta \gamma_{i t} \omega_{i t}\right)=\beta_{0}+\beta_{1} g_{i t}^{*}+\epsilon_{i t}$

Such that the hypotheses to test for equation (3) and (4) become:

$H_{1}: \beta_{0}=0$ and $\beta_{1}=1$ jointly

$H_{2}: \beta_{0}=0$ and $/$ or $\beta_{1}=1$ independently

These tests are conducted over four different time horizons i.e. 10, 15, 20 and 30 years.

Hypotheses tests are initially 4 conducted based on equation (3) for a set of increasingly comprehensive measures of capital stocks for New Zealand. Changes in the present values of real GDP per capita and changes in the present value of consumption per capita, are tested as alternative measures of well-being.

Finally, we consider the effects of possible 'wealth-dilution' a la FHV, which involves estimation, and testing of equation (4).

\subsection{Empirical literature}

Genuine savings has been tested using this testing framework in a series of studies (see Hanley et al 2015 for a review). FV and FHV analyse short panels using World Bank data. FV

\footnotetext{
${ }^{4}$ Estimates and testing based on equation (4) are presented in section 2 below.
} 
found that $H_{1}$ is rejected for all definitions of net investment. For $H_{2}$ they showed that $\beta_{1}$ is always positive and its absolute value increases with the use of more comprehensive measures of capital stock, though it declines when expenditures on education are included in the model. They speculate this reflects the extent to which education expenditure is a weak proxy of changes in the stock of human capital. $H_{3}$ is not rejected. Finally, changing the time horizon to calculate present values from 10 years to 20 years results in higher values of $\beta_{1}$. FHV use a panel of developing countries and exclude education expenditures in genuine savings and use a 20-year horizon to discount changes in future consumption. In their work, they applied increasingly comprehensive measures of changes in a country's assets base i.e. gross savings, net savings (net investment in produced capital), green savings (net savings depletion of natural capital) and pollution adjusted savings (green savings adjusted by wealth dilution effect) as in Ferreira \& Vincent (2005). The allowance for the wealth dilution effect is the key conceptual change over Ferreira \& Vincent (2005). Their main finding was that the $\beta_{1}>0$ hypothesis is not rejected for only green savings and its population adjusted equivalent. However, estimates for $\beta_{1}$ remain significantly less than 1 for all models summarised in their Table 2, p. 243. They also suggested that there was a "lack of significant impact for the adjustment for wealth dilution" (p. 246).

Finally, a number of recent studies have extended the test of GS by using longer time series data. Greasley et al. (2014b) and Hanley, Oxley, Greasley, \& Blum (2016) covered up to 250 years data for Great Britain, Germany, and USA. The key differences in terms of the genuine savings metric was the inclusion of changes in both human capital and a value of technological progress as increments to the capital stock (where they follow Pezzey (2004), by allowing for "the value of time passing" to be captured as an uncontrolled capital stock through exogenous technological progress, which expands the economy's production possibilities), as well as changes in the produced capital and natural capital. These studies found support for $\beta_{1}>0$ as the time horizon increased but only with the inclusion of a measure of the value of time (TFP growth as in this study). in their study for a panel of three countries, Hanley et al. (2016) found that with post-1870 data for consumption per capita, GS measures augmented with the value of technology, explained changes in consumption well. In particular, they estimated $\beta_{1}=1.12$ and 1.16 for horizons of 50 years depending on 
the inclusion or otherwise of the fixed effect in the panel regression models. Most recently, Greasley, Hanley, McLaughlin, \& Oxley (2016) have tested GS for Australia for 141 years.

On the contrary Lindmark, Thu, \& Stage (2018) rejected the weak sustainability hypothesis in their empirical study for Sweden and criticised GS as a forward-looking indicator for longterm sustainability.

\subsection{Data, calculations and variable definitions}

The results presented below are based on New Zealand time-series data, $1950-2015$ compiled from several national databases and publications. Variables are described in detail with data sources and descriptive statistics in the data Appendix. As a starting point, we briefly compare our key statistics with corresponding measures of Adjusted Net Savings (ANS) available from the World Bank databank for New Zealand. Table 1 and Figure 1 below present some of those comparisons. This initial first step is important as an introduction as to why our results may differ from those previously published by the World Bank, in particular, in addition to a longer time span being covered in our work, we also use data that in some cases has been approximated, yet can now be better measured and we also include some important additional data (e.g. on forestry) that was omitted from the World Bank's earlier modelling and estimation.

The World Bank has been publishing annual GS rates for a panel of approximately 160 countries including New Zealand. We compare averages of key variables in the GS model based upon our and the World Bank's estimates, and present the results as Table 1, below. The mean values of gross capital formation, consumption of fixed capital, education expenditure, nominal GDP, and population are very similar with very small differences, whereas the mean values of the remaining variables are often quite different. Two key factors are responsible for these differences: firstly, different data sources; and secondly, slight differences in estimation methods. For example, our main data sources are New Zealand national statistical yearbooks and other national databases, whereas the World Bank's key data sources are international databases (see the Appendix for further details). 
In addition, the World Bank's estimates for New Zealand do not include forestry in their GS model. The World Bank approach has been only to subtract for deforestation but to omit afforestation, the latter being relevant in the case in New Zealand. This decision to omit afforestation might be to maintain comparability between the panel of 160 countries or due to lack of data availability.

Table 1: Comparison of averages of key variables between our estimates and World Bank's estimates

\begin{tabular}{|l|l|l|l|}
\hline Variable & \multicolumn{1}{|c|}{$\begin{array}{r}\text { As mean percentage of nominal GDP } \\
\text { (otherwise specified) } \\
\text { Between 1972-2015 }\end{array}$} & Comment on source \\
\hline Gross National Savings & World Bank & Our Estimates & \\
\hline Net National Savings & $23.89 \%$ & $23.97 \%$ & Different data sources \\
\hline \multicolumn{1}{|c|}{ Gross capital formation } & $5.00 \%$ & $9.06 \%$ & Different data sources \\
\hline \multicolumn{1}{|c|}{ Consumption of fixed capital } & $23.66 \%$ & $23.63 \%$ & \\
\hline Minerals and Energy & $14.62 \%$ & $14.57 \%$ & Different data sources \\
\hline Forestry & $0.86 \%$ & $0.56 \%$ & Different data sources \\
\hline Education Expenditure & NA & $3.11 \%$ & Different data sources \\
\hline Mean of Nominal GDP (millions) & $5.21 \%$ & $5.30 \%$ & Different data sources \\
\hline Mean of Population (millions) & 3,65 & 95,877 & Different data sources \\
\hline
\end{tabular}

We have complied two new measures, Net national savings minus rents (NNSNR) and Net national savings minus rents plus forestry (NNSF), discussed in more detail later, to take these missing forestry data into account. The incorporation of the missing forestry data plays a vital role in considering the sustainability of the New Zealand's economy and future wellbeing, as a whole.

From these data we construct increasingly comprehensive measures of savings (as potential predictors of future wellbeing.

1. Net national savings (NNS)

2. Net national savings minus rents (NNSNR)

3. Net national savings minus rents plus forestry (NNSF)

4. Genuine savings (GS)

5. TFP growth series for NNSNR, NNSF and GS series

\subsection{Net National Savings (NNS)}

According to the World Bank methodology (Bolt, Matete, \& Clemens, 2002), Gross National Savings (GNS) are calculated as the difference between gross national income and public and 
private consumption plus net current transfers (n.b. savings are seen as the 'residual' and not measured directly). NNS is calculated as the difference between gross national savings and depreciation/consumption of fixed capital (CFC). For this study, data for GNS and CFC are available from Statistics New Zealand (SNZ).

NNS exhibited a declining trend from the 1970s-1990s and subsequently a modest trend increase thereafter.

Figure 1: Time series comparisons of key variables between our estimates and World Bank's estimates
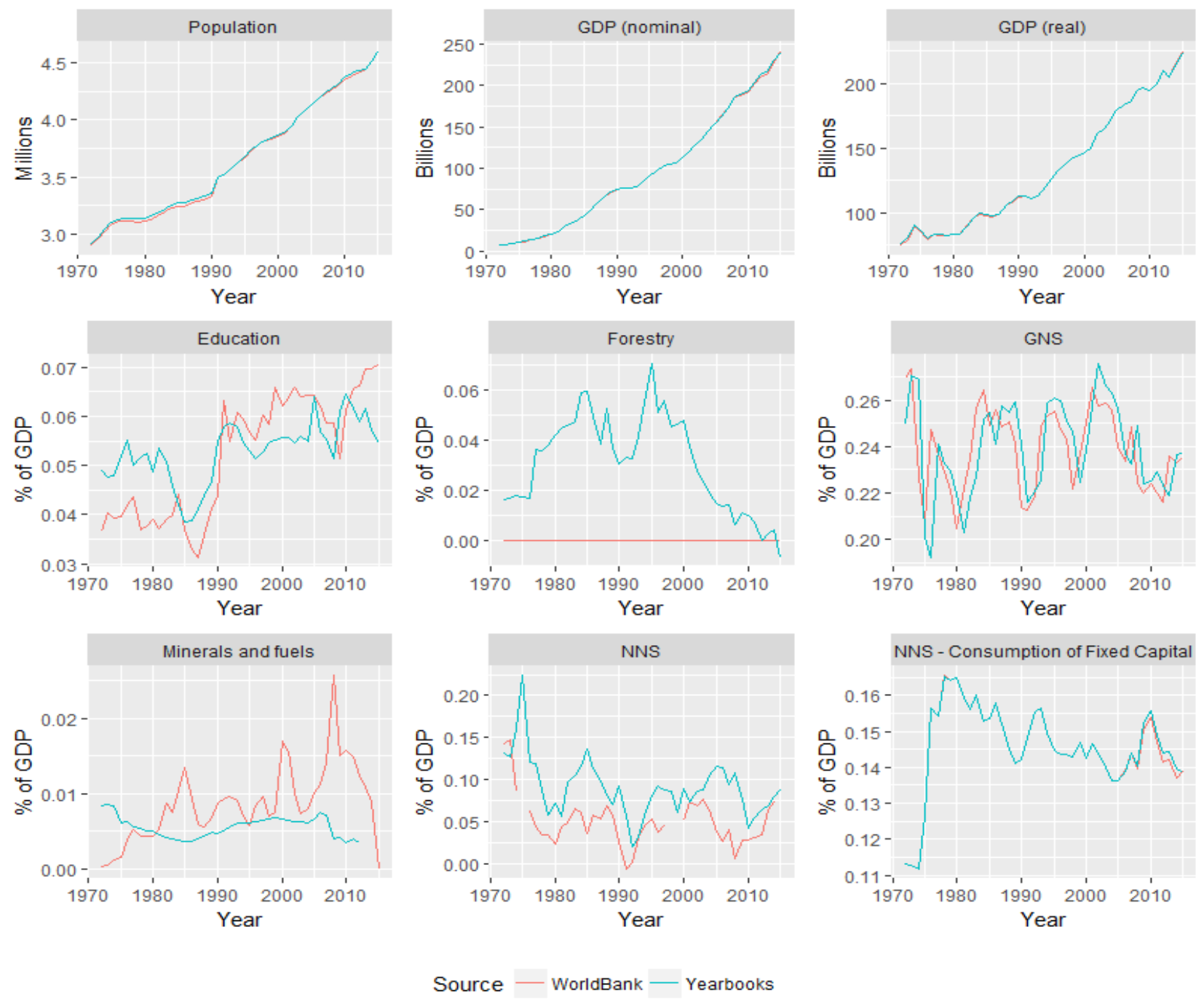

\subsection{NNSNR}

Our measure of NNSR is computed by the subtracting natural resource rents from NNS. Rents are obtained by subtracting average costs from market returns, this is standard 
framework for estimating resource rents (Bolt et al. (2002)..$^{5}$ These rents are primarily derived from the mining of natural resources (excluding forestry) which include metals such as gold, silver, magnetite (iron) and non-metals rock, sand and gravel, limestone, amorphous silica, perlite, serpentine, silica sand, zeolite, iron ore, zinc etc.

Annual time-series data on the aggregate market value of all minerals are provided by: The New Zealand Official Yearbooks, NZOYBs hereafter, between 1950 - 1993; and by the Mining Production Statistics annual publications by the Ministry of Business Innovation and Employment (2000 - 2015). Six missing vales from 1994 - 1999 are imputed using linear extrapolations. Data for labour employed in the mining sector and their average wages are also extracted from NZOYBs. This allows our numerical estimate of GS, as far as NNSNR are concerned, to correspond with its theoretical equivalent, and this holds for the World Bank's estimates as well.

The New Zealand economy has benefited, in a GDP sense, from the extraction of nonrenewable metal and mineral resources. There has been a rise in activity in the mining industry and in recent years this industry's contribution to GDP has risen by approximately 1 percent since 2007.

\subsection{NNSF}

This component of GS is estimated by adding to NNSNR the rents from forest depletion, which are excluded from the World Bank estimates for most of the countries they consider. In the case of New Zealand, the value assigned to forestry by the World Bank is set equal to zero for the whole period considered.

The volume of the standing forest includes the total area of both natural and planted forest in hectares. The volume of standing forest in cubic meters is estimated by multiplying the area covered by the forest (in hectares) by the average volume per hectare. These data were extracted from the New Zealand Ministry of Primary Industries in the National Exotic Forest Description (NEFD) and Forest Owners Association (FOA) facts and figures reports. The cost of production is estimated from the number of people employed in the forestry industry and

\footnotetext{
${ }^{5}$ See appendix for details on rent calculations.
} 
the real wage, and market prices are determined by the average export price of all forest products from New Zealand available from NZOYBs.

Forestry is a significant industry in New Zealand as it has been contributing to an average of $3.4 \%$ of GDP annually over the period of this study, which is more than double that of the contribution to GDP from all other natural resources combined. Exports from forestry are estimated to reach $\$ 4.8$ billion in 2017 , which is almost triple of the all merchandised exports (NZIER, 2017).

In addition, New Zealand forests are a strong carbon sink (Hollinger, Maclaren, Beets, \& Turland, 1993, Tate et al., 2000) which, from a New Zealand national accounting perspective, would offset the 'damages from carbon dioxide emissions' making these less relevant to our GS model.

\subsection{Genuine Savings (GS)}

GS is obtained from the sum of NNSF and investments in education as a proxy of human capital as per the World Bank methodology. Data for government spending on education at all levels (i.e. including primary, secondary, tertiary, etc.) are obtained from NZOYBs for the period 1950 - 1971 and from SNZ for 1972 - 2015. There are certain pros and cons of using education expenditure to a for proxy human capital. Government spending on education naturally fits into the GS framework, which articulates the varying components of investment. Nevertheless, human capital formation does not equate to spending on education (Hanley et al., 2016). For instance, human capital includes the skill set acquired in the workplace, voluntary online learning, etc. In addition, international migration of educated New Zealanders plays a vital role in terms of human capital available to the country. However, the brain drain from New Zealand is offset by the incoming professional immigrants to New Zealand, which many see as brain exchange, rather than brain drain (Glass, Choy, \& others, 2001).

3.5 A Total Factor Productivity (TFP) growth series for the NNSNR, NNSF and GS measures: denoted NNSNRtp, NNSFtp and GStp

The inclusion of exogenous TFP growth (as a measure of technological progress denoted (tp) into the assessment of a country's capital stocks has been advocated by many including 
Pemberton \& Ulph (2001) and Weitzman (1997). The underlying assumption of technological progress as an uncontrolled stock of capital associated with the 'value of time passing' which can be measured by TFP growth, is that all technological progress is exogenous and it increases the possibilities of higher consumption in future (Pezzey et al., 2006, Pezzey, 2004). They further emphasize that the shifts in the terms of trade of natural resource exports should be a part of the value of time. Arrow et al. (2012) also included the value of technological progress as a component of a country's capital stocks. The case of including TFP growth in a comprehensive investment measure appears strong, mainly because of the established evidence that residual productivity plays a vital role in the growth of consumption for OECD countries (Ferreira \& Vincent, 2005). However, there is limited evidence that the terms of trade favour the export of natural resources in the long-run (Blattman, Hwang, \& Williamson, 2007), therefore, we limit the augmentation of GS for the value of TFP growth by using a measure of trend growth in TFP. An annual index of TFP is given by:

$T F P=G D P /\left(\right.$ Labour $^{\alpha}$ Capital $\left.^{1-\alpha}\right)$

Where labour is the measure of hours worked, and capital is the stock of reproduced capital, and $\alpha$ is the elasticity of the output in relation to the labour. The resulting TFP index reinforces the interpretations of New Zealand economic growth. For instance, Fagerberg (2000) show that New Zealand achieved a total TFP growth of 51.3\%, (1973 - 1990), with an average annual growth of $2.4 \%$. Similarly, Färe, Grosskopf, \& Margaritis (2001) studied relative TFP trends for Australia and New Zealand manufacturing sectors and concluded that New Zealand's TFP record in this sector has been slightly better on average than that of Australia.

Trend growth TFP estimates can be used to support the valuation of exogenous technological progress. Arrow et al. (2012) simply augmented their measure of comprehensive investment with the current value of TFP growth to show how technical progress increases the level of current income. Therefore, considering time as an uncontrolled capital stock means TFP's contribution to the change in wealth in any year should be included in our measure of GS. Our method to measure how TFP growth contributes to changes in the value of wealth follows Pezzey et al. (2006) and Hamilton \& 
Hartwick (2005b) where we use the annual index of TFP from (Greasley \& Madsen, 2016) (equation 1) based on their preferred TFP (BDL) variant. Trend growth from these data for each year 1950-2015 was extracted using a Kalman Filter and used to construct a measure of the value of technological progress and to augment GS, Green and Super Green series over $10,15,20$ and 30 years horizons. For sensitivity analysis, we used the present value of future changes in TFP of the aforementioned series with $1.4 \%$ per year and $2.8 \%$ per year discount rates to value technological progress, where the discount rates are matched with those for consumption and GDP per capita.

\subsection{Consumption per capita and GDP per capita}

Net present values for the future changes in real consumption per capita (C), real GDP per capita (GDP) and TFP data series as a proxy for technological change (tp) are estimated following Ferreira et al. (2008) over 10, 15, 20 and 30 years horizons with a 2.8\% per year discount rates. ${ }^{6}$

\subsection{Some comparisons of the measures}

The increasingly comprehensive measures NNS, NNSR, NNSF, GS, NNSRtp, NNSFtp and GStp are illustrated in Figures $2-7$, below. The values of all these measures, in real terms and as a percentage of GDP, were positive over the study period i.e. 1950 - 2015. Although there was a large decline in the measures in 1975 because of the lowest value of net exports in the period of 1950 - 1987, overall there was a steady upward trend for all data series in realterms, except the NNSF series. This was mainly due to a sharp decline in the year-on-year changes in the forest volume. Year-on-year changes in forest volume peaked in 1996, as shown in Figure 4, followed by a sharp decline in following years, as land use switched to dairy farming and agriculture due to changes in profitability. This has subsequently resulted in the decline in the GS to GDP ratio since 1995 as shown in Figure 3.

\footnotetext{
${ }^{6}$ The long-run discount rate is derived from the mean nominal discount rate minus the rate of inflation, see appendix for sources. $2.8 \%$ is our benchmark discount rate, this rates sits just blow recent New Zealand Treasury discount rates projects over $10,15,20$, and 30 years (3.06\%, 3.38\%, 3.57\%, 3.87\%). Spot rates from: http://www.treasury.govt.nz/publications/guidance/reporting/accounting/discountrates
} 
Figure 2: Alternative measures of future well-being (real per capita)

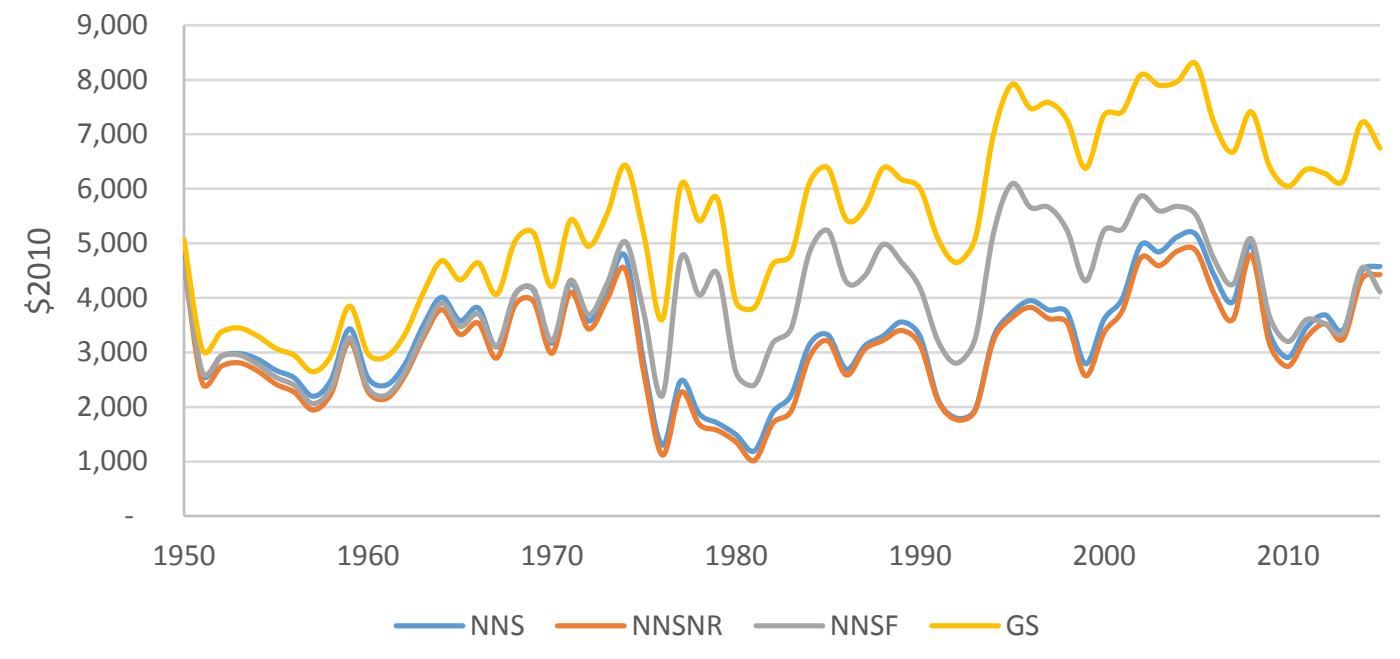

Figure 2: Alternative measures of future well-being as a percentage of GDP

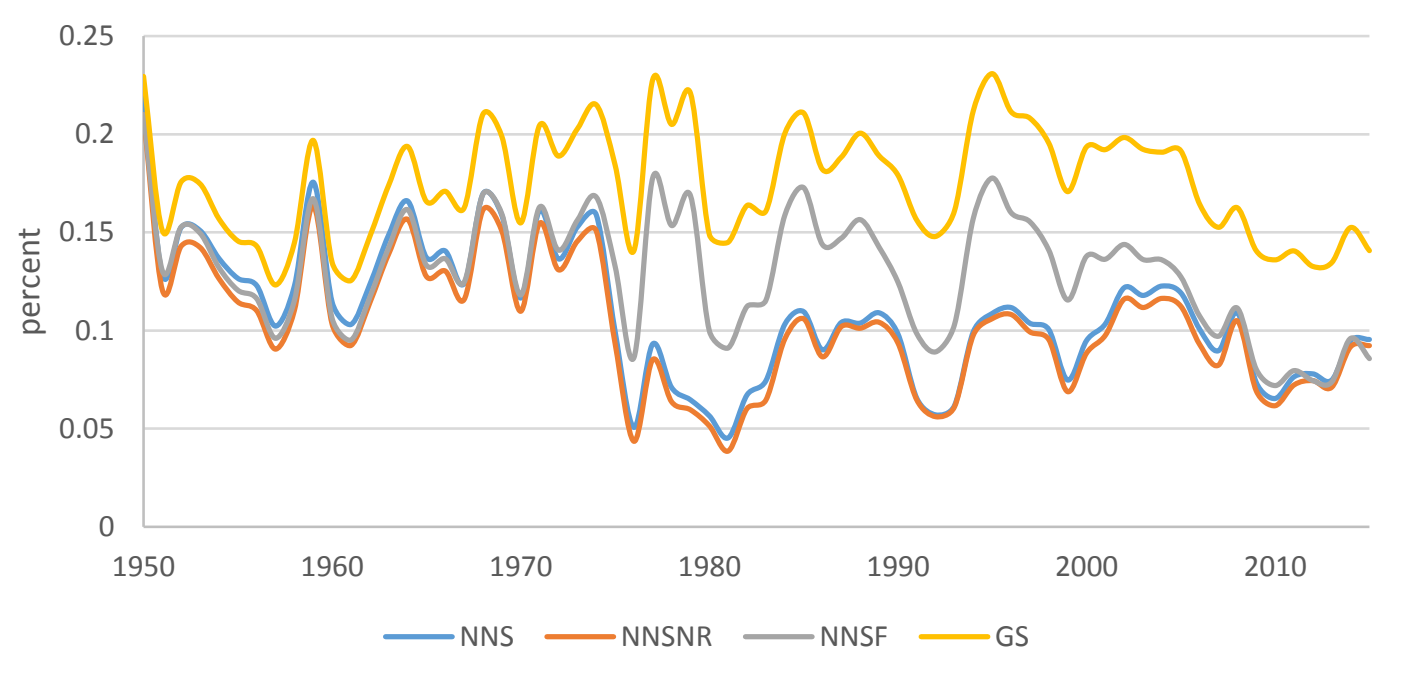

Figure 3: New Zealand forest volumes

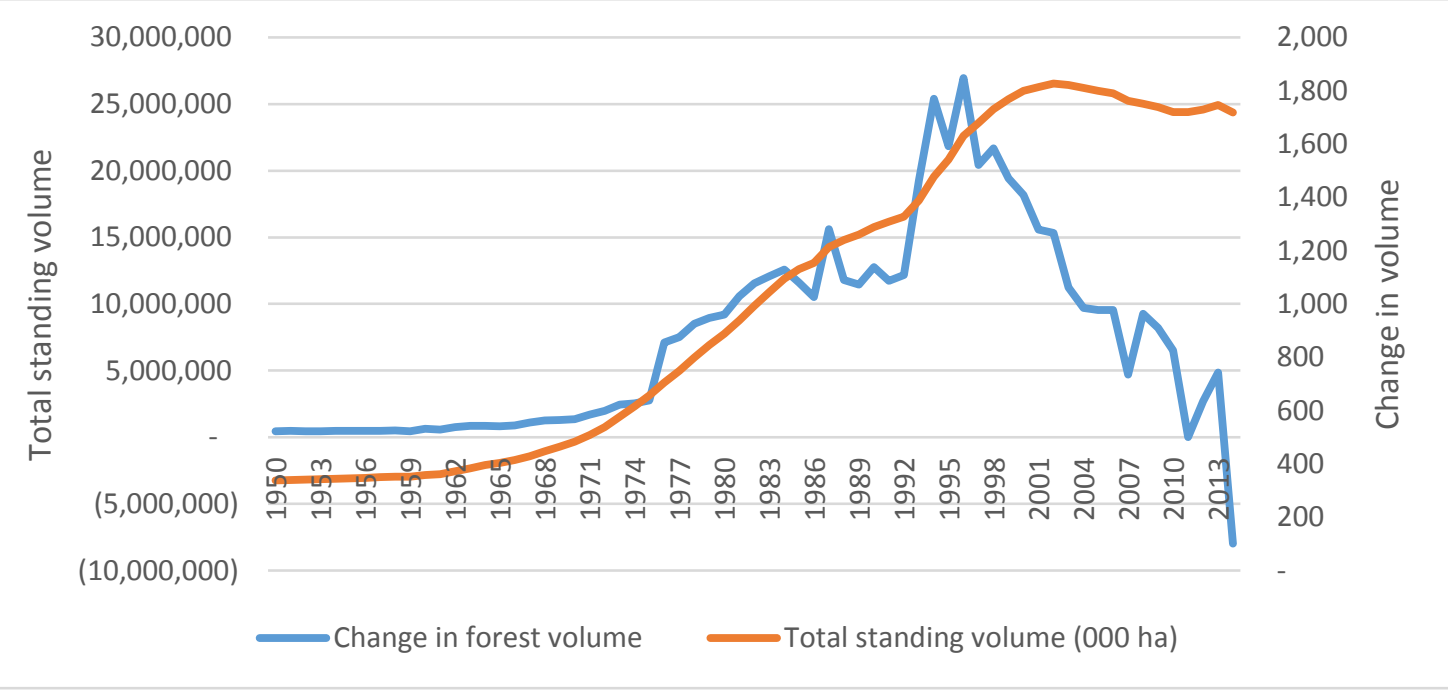


Figure 5a: PV of technological progress augmented NNSNR measure as a percentage of GDP at $2.8 \%$ discount rate over $t=10,15,20,30$ year horizons

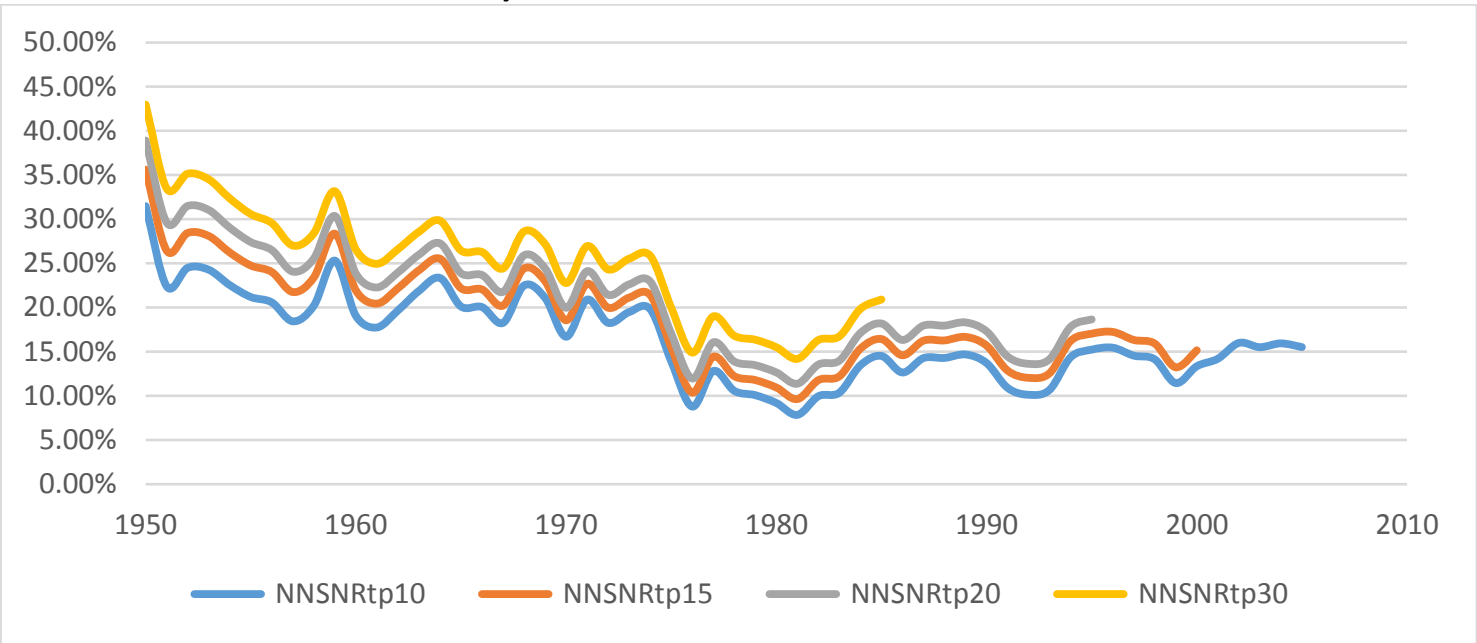

Figure 5b: PV of technological progress augmented NNSF measure as a percentage of GDP at $2.8 \%$ discount rate over $t=10,15,20,30$ year horizons

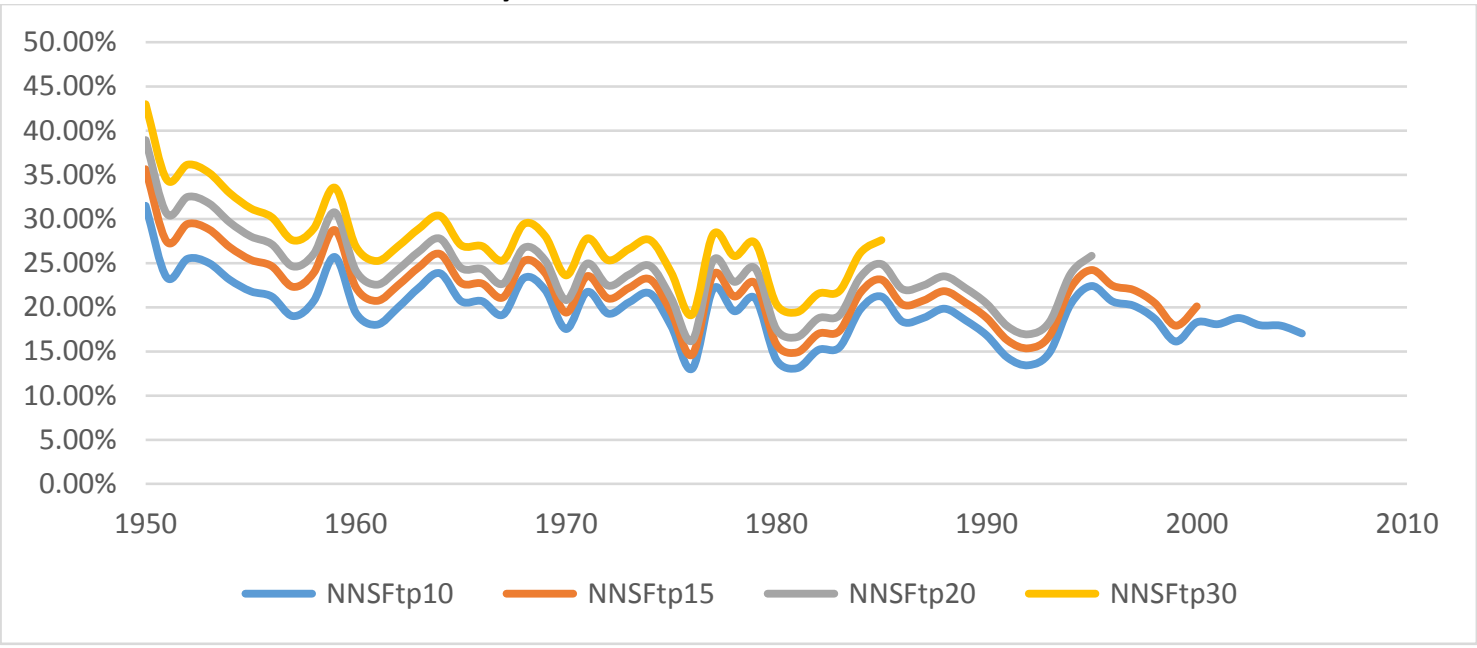

Figure 5c: PV of technological progress augmented GS measure as a percentage of GDP at $2.8 \%$ discount rate over $t=10,15,20,30$ year horizons

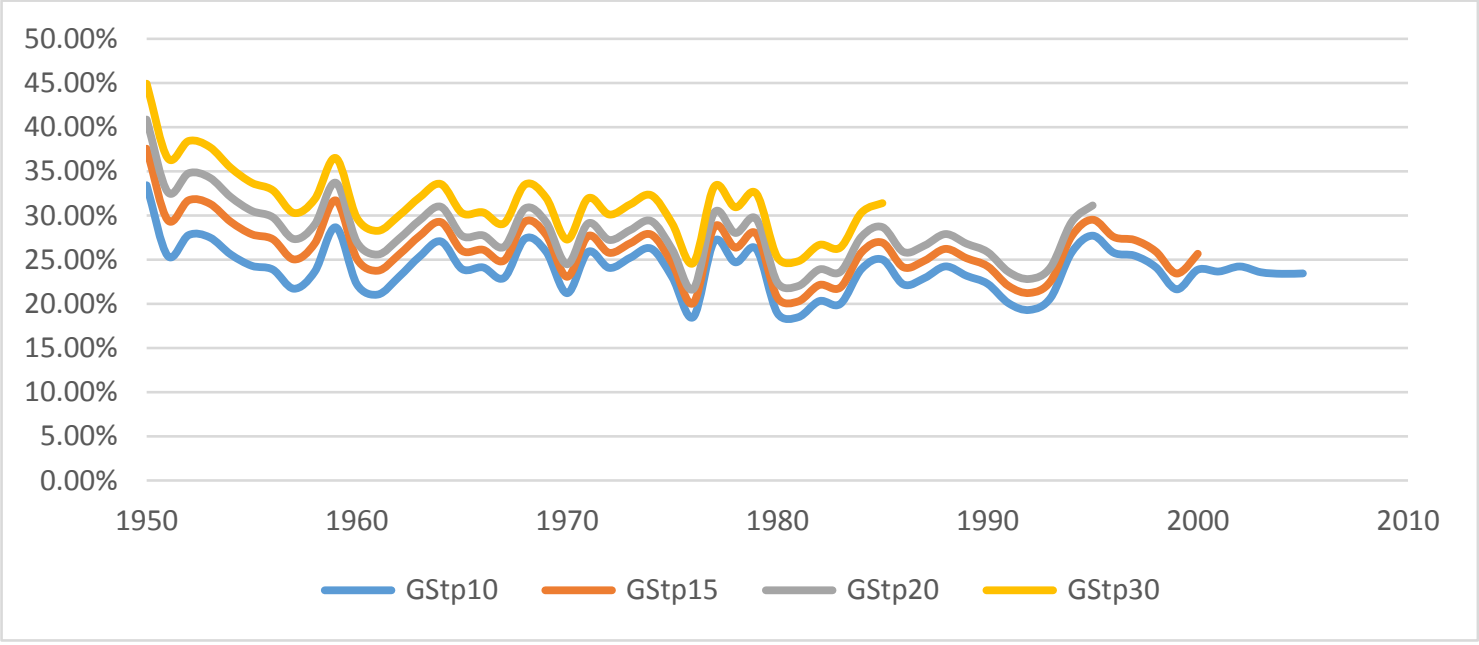


Figure 6: PV of future changes in real GDP over $t=10,15,20,30$ year horizons with $2.8 \%$ discount rate

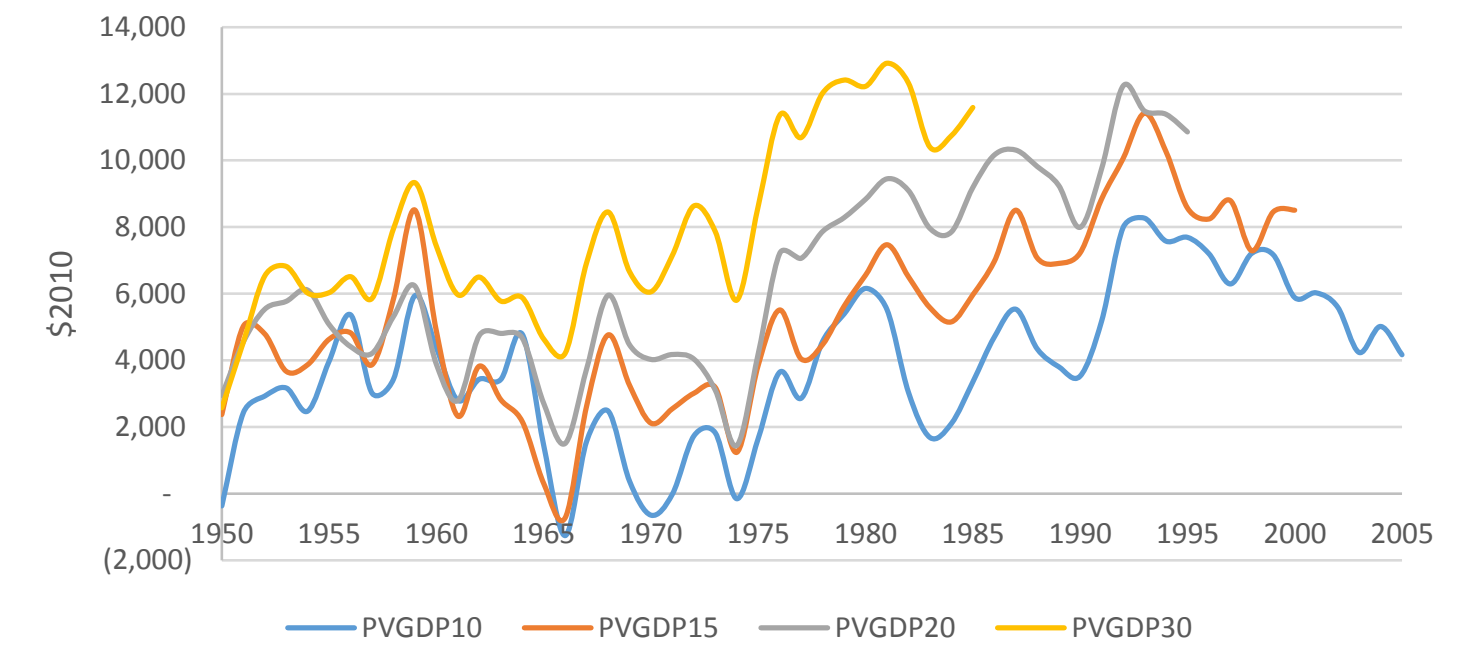

Figure 7: PV of future changes in real consumption over $t=10,15,20,30$ year horizons with $2.8 \%$ discount rate

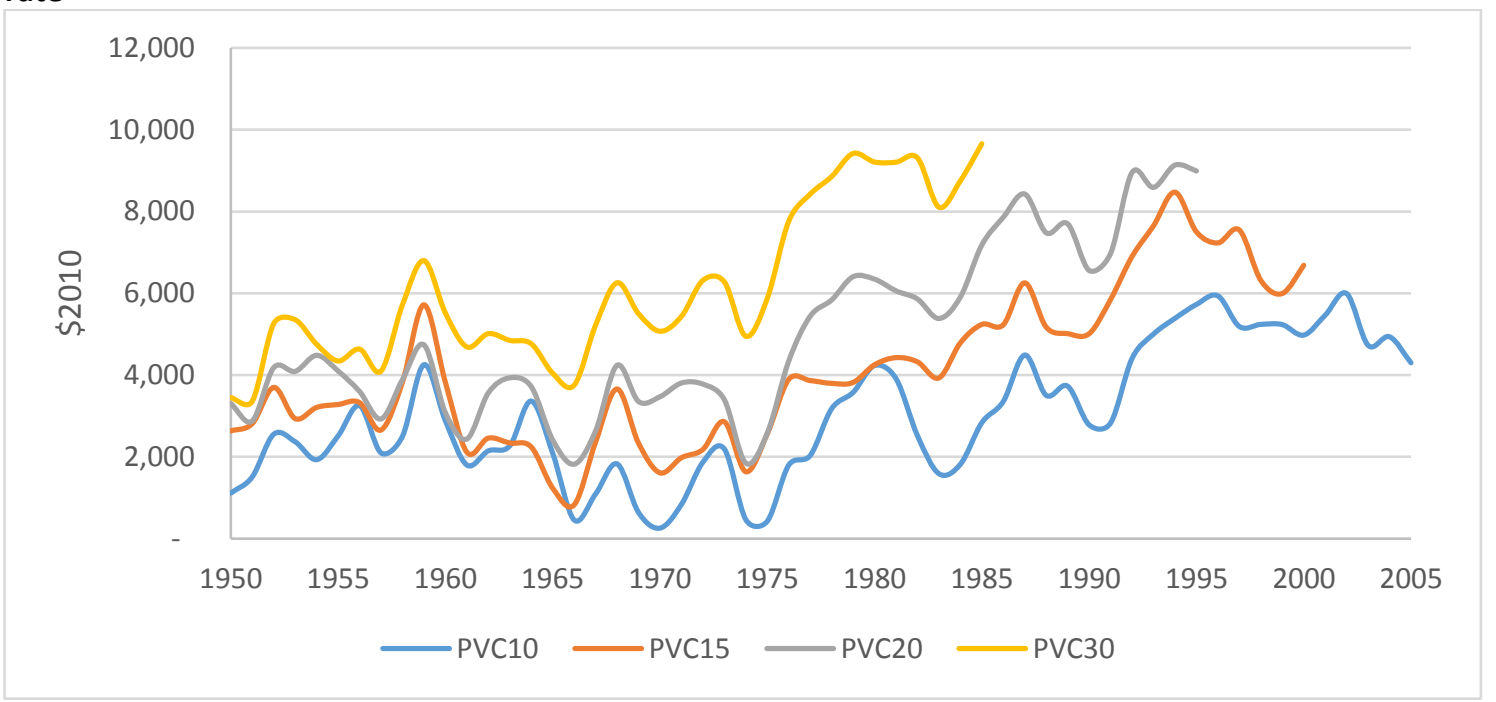

\subsection{Varying population growth and wealth dilution}

With varying population growth, FHV (2008) show that the relation between GS and the PV of future changes in consumption is altered by a wealth-dilution effect (equation 6). The wealth-dilution effect arises from the sharing of a given amount of capital between more people. So long as population growth is positive, wealth dilution reduces GS per capita. The measure of aggregate wealth used here to calculate the wealth-dilution effect follows the World Bank's 'top-down' construction method. The World Bank measure identifies total 
wealth with the PV of an estimated stream of private and public consumption over 20 years. We discuss the effects of wealth-dilution on our estimates in Section 4 below.

\subsection{Measuring well-being over time}

We followed FHV (2008) who state that "economic theory predicts that the current change in national wealth, broadly defined to include natural and human capital as well as produced capital ("genuine savings"), determines whether the present value of future changes in consumption is positive or negative" in order to calculate the net present values (NPVS) of future changes consumption per capita and future changes in GDP per capita in real terms as measures of well-being. Both of these indicators align closely with the theoretical framework of GS. Data for these series are extracted from SNZ's Info share facility from 1972 to 2015, and the earlier data were sourced from NZOYBs. NPVs for these well-being measures are also calculated for four time horizons i.e. $10,15,20$ and 30 years using a $2.8 \%$ discount rate. Trends in these data series are summarised in Figure 6.

\subsection{Empirical results for testing the implications of a GS approach applied to}

\section{New Zealand}

This section provides a detailed discussion of the estimation methods and presents results of the various tests in relation to the GS model based upon the different measures of GS and well-being discussed above. Our empirical GS models are developed based upon two alternative measures of future well-being: real consumption per capita (C) and real GDP per capita (GDP), which are linked to increasingly comprehensive measures of savings, including technology augmented measures.

Using the theoretical framework, estimation and testing methods discussed earlier, let us first consider the relationship between the present value of real GDP per capita and NNS, NNSNR, NNSF and GS reported in Table 2.

Based upon equations (iii) and (iv) the following hypotheses are considered:

$H_{1}: \beta_{0}=0$ and $\beta_{1}=1$ jointly

$H_{2}: \beta_{0}=0$ and $/$ or $\beta_{1}=1$ independently. 
To avoid any confusion, there is no intention to claim that equations (iii) and (iv) are the 'best fitting' models to explain the LHS variable. The estimates (and their standard errors) are used within an equation that constitutes a test statistic and not a model, in much the same way as one would not regard the LHS of a Dickey-Fuller test to represent the best fitting explanation (model) of the LHS variable.

Estimates of $\beta_{1}$ fall in the range of -1.5 to 1.01 . The proposition for $\beta_{1}$ supports the tests of GS as an indicator of future per capita income as discussed earlier. In the case of NNS and NNSNR, the hypothesis $\beta_{1}=1$ is rejected which means that the PV of future changes in real GDP per capita are lower than those indicated by the level of savings. Another interesting pattern that emerges is that the value of $\beta_{1}$ increases as we include more factors as we move from NNS towards the GS measure.

Table 2: Summary of results with the PV of the change in GDP per capita with a $2.8 \%$ discount rate over a 20 year horizon

\begin{tabular}{llllll}
\hline $\mathbf{1}$ & $\mathbf{2}$ & $\mathbf{3}$ & $\mathbf{4}$ & $\mathbf{5}$ & $\mathbf{6}$ \\
Dependent & Independent & $\boldsymbol{\beta}_{\mathbf{0}}$ & $\boldsymbol{\beta}_{\mathbf{1}}$ & $\boldsymbol{\beta}_{\mathbf{1}} \mathbf{1}\left(\boldsymbol{\chi}^{\mathbf{2})}\right.$ & $\boldsymbol{\beta}_{\mathbf{0}}=\mathbf{0}, \boldsymbol{\beta}_{\mathbf{1}}=\mathbf{1}\left(\boldsymbol{\chi}^{\mathbf{2}}\right)$ \\
\hline PVGDP & GNS & 188.66 & $0.98 * * *$ & 0 & 0.04 \\
PVGDP & NNS & $10908.31 * * *$ & $-1.51 * * *$ & $33.28 * * *$ & $118.58 * * *$ \\
PVGDP & NNSNR & $10181.9 * * *$ & $-1.35 * * *$ & $26.82 * * *$ & $115.65 * * *$ \\
PVGDP & NNSF & $3674.04 * *$ & $0.77 *$ & 0.3 & $47.73 * * *$ \\
PVGDP & GS & 1691.59 & $1.01 * * *$ & 0 & $20.57 * * *$ \\
PVGDP & NNSNRtp & $13399.47 * * *$ & $-1.29 * * *$ & $44.45 * * *$ & $52.5 * * *$ \\
PVGDP & NNSFtp & $4959.93 *$ & 0.24 & $2.89 *$ & 3.15 \\
PVGDP & GStp & 128.72 & $0.86 * *$ & 0.14 & $4.94 *$ \\
\hline
\end{tabular}

NOTES: Dependent variable is the present value of future GDP per capita in real terms over 20 years time horizon discounted at $2.8 \%$ discount rate. Independent are right-hand side variables. The technological progress (tp) series based on TFP are also discounted at $2.8 \%$ over 10, 15, 20 and 30 years time horizon.

For column 3, hypotheses $\mathrm{HO}: \beta \mathrm{O}=0 ; \mathrm{H} 1: \beta O \neq 0$ and for

column $4, \mathrm{HO}: \beta 1=0 ; \mathrm{H} 1: \beta 1 \neq 0$ are tested using t-statistics where $*$ denotes results are significantly different from zero at $10 \%$ level, $* *$ at $5 \%$ and $* * *$ at $1 \%$. For

column 5 , hypothesis $\mathrm{HO}: \beta 1=1 ; \mathrm{H} 1: \beta 1 \neq 1$ and for

column 6 , the joint hypothesis is $H 0: \beta 0=0 \& \beta 1=1 ; H 1: \beta 0 \neq 0 \& \beta 1 \neq 1$ are tested using a Wald Test which is distributed as $\chi 2$ distribution with 1 (for column 5) or 2 degrees of freedom (for column 6 ) respectively.

For example, $\beta_{1}$ for the NNSNR, which counts mining as negative savings, is higher than that of NNS. Similarly, this value increases further when forestry is taken into the account in the NNSF. Thus GS, with a broader measure of natural capital, forestry and human capital has the highest value of its coefficient in Tables 2. Greasley et al. (2014b) and Greasley et al. (2016) have shown similar patterns in their results. Although the GS model is designed for infinite time horizons, in most of our results, we find the 20 years horizon for the two 
dependent variables, real GDP per capita and real consumption per capita, most relevant to New Zealand. This may be a function of the length of our time series - something we would hope to consider if we could construct longer time series. See the Appendix for a full set of results.

It seems that the estimates for NNS and NNSNR over a 20 years time horizon, with a $2.8 \%$ per year discount rates, have negative values. In the case of GS, the estimate of $\beta_{1}$ is 1.01, which, unsurprisingly is not different from 1.

The present value of future consumption per capita provides an alternative measure of well-being and it aligns somewhat better with theory (Greasley et al., 2014). The estimates of $\beta_{1}$ over the 20 years horizon show rising values of $-0.71,0.58,0.87,0.93$ as the measure of savings becomes more comprehensive. It is noteworthy that only the GS measure in Table 3 also supports the stronger joint hypotheses, with non-rejection of $\boldsymbol{\beta}_{0}=\mathbf{0}, \boldsymbol{\beta}_{1}=1$. We observe a somewhat similar pattern as in the case of real GDP per capita, suggesting in the work presented here that both GDP per capita and consumption per capita performed almost equally well as indicators of future well-being in the case of New Zealand.

Table 3: Summary of results with PV of change in consumption per capita (2.8\% discount rate) 20 years horizon

\begin{tabular}{llllll}
\hline $\mathbf{1}$ & $\mathbf{2}$ & $\mathbf{3}$ & $\mathbf{4}$ & $\mathbf{5}$ & $\mathbf{6}$ \\
Dependent & Independent & $\boldsymbol{\beta}_{\mathbf{0}}$ & $\boldsymbol{\beta}_{\mathbf{1}}$ & $\boldsymbol{\beta}_{\mathbf{1}}=\mathbf{1}\left(\boldsymbol{\chi}^{\mathbf{2}}\right)$ & $\boldsymbol{\beta}_{\mathbf{0}}=\mathbf{0}, \boldsymbol{\beta}_{\mathbf{1}}=\mathbf{1}\left(\boldsymbol{\chi}^{\mathbf{2}}\right)$ \\
\hline PVC & GNS & -1015.26 & $0.94 * * *$ & 0.08 & $29.05 * * *$ \\
PVC & NNS & $7050 * * *$ & $-0.71 * *$ & $25.19 * * *$ & $70.72 * * *$ \\
PVC & NNSNR & $6551.38 * * *$ & -0.58 & $20.24 * * *$ & $72.43 * * *$ \\
PVC & NNSF & 1823.81 & $0.87 * * *$ & 0.21 & $22.63 * * *$ \\
PVC & GS & 560.44 & $0.93 * * *$ & 0.11 & 0.99 \\
PVC & NNSNRtp & $8442.9 * * *$ & $-0.65 * *$ & $37.27 * * *$ & $39.54 * * *$ \\
PVC & NNSFtp & 1563.45 & $0.54 *$ & 2.08 & $20.11 * * *$ \\
PVC & GStp & -1749.93 & $0.91 * * *$ & 0.12 & $76.89 * * *$ \\
\hline
\end{tabular}

NOTES: See the notes from Table 2 for the explanation of null and alternative hypotheses and the levels of significance.

In their seminal study, FHV could not establish that GS had a significant and positive effect on the future consumption of OECD countries. Longer time horizons reiterate the importance of including technological progress in the measure of savings and wealth. A number of studies have emphasised how the omission of technological progress from the estimation of GS can provide misleading results, for example, see (Arrow et al., 2012, Pezzey 
et al., 2006, Pezzey, 2004, Weitzman, 1997). Following their suggestions, a number of empirical studies have included technological progress in their model of GS, for example, (Blum et al., 2017a, Blum et al 2017b, 2016, Greasley et al., 2014b, 2016, Hanley et al., 2016). Results of estimates of TFP growth series using alternative indicators for NNSNR, NNSF and GS series are also reported in Tables 2 and 3. It is worth noting that GS, by definition, includes the value of human capital as expenditure on education, which might be partially reflected in TFP; and using TFP for the NNSNR, NNSF and GS highlights the possibility of some double counting.

Technology augmented results exhibit the incremental pattern (increase) in the value of $\beta_{1}$ as the measure of savings become more comprehensive. There are nevertheless, situations where the value of $\beta_{1}$ itself is not significant. The values of $\beta_{1}$ estimates are close to 1 for the wellbeing measure PVGDP based upon the GS or GStp variants as shown in Table 2. These results make a strong case for the use of GS and its technology augmented version, in explaining the real GDP per capita measure (PVGDP). Turning to the PV of changes in consumption per capita (PVC), again the GS and GStp variants do not reject the null hypothesis $\boldsymbol{\beta}_{\mathbf{1}}=\mathbf{1}$, and in the case of GS, $\boldsymbol{\beta}_{\mathbf{0}}=\mathbf{0}, \boldsymbol{\beta}_{\mathbf{1}}=\mathbf{1}$.

The Appendix as Tables A1, A2, and A3 present some additional statistics and results. One of the key patterns shown there is that, when the time horizons are matched for dependent and independent variables, $\beta_{1}$ exhibits lower levels of significance at 10 years time horizon which, increases or reaches a maximum level in most cases at 20 years horizon and declines again beyond that. This suggests (with these data) that the 20 years horizon is the most relevant for a New Zealand GS model given the extent of time-series data covering the period $1950-2015$. This is not to say that a longer time series may find that such horizons are extended.

In summary, for two alternative measure of future well-being (real GDP per capita and real consumption per capita), our results align closely with the theoretical relationship between GS and future well-being, and provide some initial support for the indicative capacity of the GS model, compared to previously published studies. 


\subsection{Genuine Saving and changes in future Wellbeing}

The results presented so far suggest that New Zealand has been on a (weakly) sustainable development path over the period of consideration. Of equal interest is the theoretical literature, which relates GS to changes in wellbeing into the future. For example, Arrow et. al., (2012) show that intergenerational wellbeing is rising over future periods if GS is positive when evaluated at the correct shadow prices in the current period. Hamilton and Withagen (2007) show that, if genuine saving is positive and growing at a rate lower than the interest rate over an unbounded interval, then social welfare is everywhere increasing over this interval. Furthermore, FHV (2008) show that in any period $t$, the value of $g$ (GS) is equal to the discounted value of changes in per capita consumption from $t$ to infinity if the consumption rate $\rho$ is adjusted downwards by the (constant) population growth rate. If population grows at a varying rate, then the relationship between GS and the PV of changes in future consumption is altered. From this FHV (2008) derive a reduced form relationship between GS and the PV of changes in future consumption (presented above as equations (5) and (6)).

The results presented so far effectively relate to whether GS is consistently positive from which we can then infer whether the economic data is consistent with weak sustainability. In the next section we will expand our estimation and testing to include the effects of wealth-dilution.

\subsection{Wealth-dilution effects}

FHV (2008) show that the relationship between $\mathrm{GS}(\mathrm{Cl})$ and the PV of future changes in consumption is altered by a wealth-dilution effect (equation 6). The wealth-dilution effect arises from the sharing of a given amount of capital between more people. So long as population growth is positive, wealth dilution reduces $\mathrm{Cl}$ per capita. The measure of aggregate wealth used here to calculate the wealth-dilution effect follows the World Bank's 'top-down' construction method, which identifies total wealth with the PV of an estimated stream of private and public consumption over a 20 -year horizon. 
A characteristic of New Zealand (and Australia) is that population has been growing much more rapidly than in Western Europe and the USA. From Greasley et al. (2017) for their period of interest (1946-2000) population grows, on average, at a rate of $1.75 \%$ in Australia; 0.33\% in Britain; 0.63\% in Germany and $1.28 \%$ in the USA. In the case of New Zealand; 19502015 saw population grow at an average rate of $1.38 \%$. As a consequence, the possibility of a significant wealth-dilution effect (the spreading of capital among a larger population) may have particular resonance for New Zealand (and Australia).

The estimates of the non-technology and technology-augmented measures of GS (over a 20 year horizon) are presented as Table 4, below, and are based upon equation (6), which adjusts the savings-GDP and savings-consumption relationship for possible wealth-dilution. The form of the adjustment includes a wealth-related variable on both sides of the equation; hence, when we report the estimation results, we consider both OLS and 2SLS estimates, where the latter are used to counter any possible bias from endogeneity.

In terms of the actual results presented as Table 4 , in all cases the point estimates of $\beta_{1}$ all exceed unity, however in three cases not significantly so. In terms of the alternative measures of wellbeing, 2SLS rejects $\beta_{1}=1$ when changes in real GDP per capita is used however, when consumption is the basis of the measure the hypothesis is not rejected for the non-technology augmented version of GS.

Table 4: Summary of results with the PV of the change in GDP per capita and PV of the change in Consumption, allowing for wealth-dilution with a $2.8 \%$ discount rate over a 20 year horizon.

\begin{tabular}{llllllll}
\hline Model & Dependent & Independent & $\boldsymbol{\beta}_{\mathbf{0}}$ & $\boldsymbol{\beta}_{\mathbf{1}}$ & $\boldsymbol{\beta}_{\mathbf{1}} \mathbf{1}\left(\boldsymbol{\chi}^{\mathbf{2})}\right)$ & $\begin{array}{l}\text { Weak } \\
\text { instruments }\end{array}$ & $\begin{array}{l}\text { Wu- } \\
\text { Hausman }\end{array}$ \\
\hline \multirow{2}{*}{ OLS } & GDPWD & GStpWD & -569.94 & $1.47 * * *$ & $4.64 * *$ & & \\
& GDPWD & GSWD & $4222.78 * * *$ & $1.28 * * *$ & 2.25 & & \\
\cline { 2 - 8 } 2SLS & GDPWD & GStpWD & -1587.69 & $1.69 * * *$ & $8.44 * * *$ & $58.27 * * *$ & $7.07 * *$ \\
& GDPWD & GSWD & $3940.11 * * *$ & $1.42 * * *$ & $4.28 * *$ & $94.85 * * *$ & $6.21 * *$ \\
\multirow{2}{*}{ OLS } & CWD & GStpWD & $-1496.03 *$ & $1.32 * * *$ & $4.1 * *$ & & \\
& CPWD & GSWD & $2841.54 * * *$ & $1.13 * * *$ & 0.85 & & $3.44 *$ \\
\cline { 2 - 8 } 2SLS & CWD & GStpWD & $-2001 * *$ & $1.43 * * *$ & $6.34 * *$ & $61.52 * * *$ & $3.51 *$ \\
\hline
\end{tabular}

$* \mathrm{p}<0.1 ; * * \mathrm{p}<0.05 ; * * *$. WD refers to Wealth-Dilution; tp refers to technological progress augmented 
With all point estimates of $\beta_{1}$ exceeding unity (typically but not exclusively, significantly) our wealth dilution adjusted estimates suggest that our broadest measure of GS (that includes technology augmentation) understates changes in wealth, at least in the context of understanding consumption changes over finite horizons of up to 20 years ahead.

There are, of course, other possibilities as to why the point estimates of $\beta_{1}$ in Table 4 all exceed unity. These include that the wealth dilution effects of population growth are overstated, or that the consumption discount rate is understated. Furthermore, much of the recent population growth since 1950 has been from immigration, and the extent to which migrants embody human capital not measured in the New Zealand national accounts, changes in its wealth might be understated in accounting for GS. The consumption discount rate embedded in the estimates may not correctly capture the degree of uncertainty surrounding the future and may understate the value of immediate consumption. Finally, the fact that the technology augmented results in the wealth dilution estimates exceed those without augmentation suggests that our measure of the effects of technological change (based upon TFP growth) are not capturing the actual contribution coming from technological change.

\subsection{Savings-gaps}

So far we have focused upon tests of (weak) sustainability and established that, even with wealth-dilution accounted for, New Zealand has been enjoying positive values for GS throughout the period. This in turn suggests that the results presented so far suggest that GS has been consistently positive over the period 1950-2015 from which we can infer that the data are consistent with weak sustainability.

However, as the World Bank (2011, p.41 \&43) conclude that:

"Even developed countries such as the United States and New Zealand have had positive ANS, but a decline in per capita wealth because saving has not been sufficient to compensate for population growth."

And for 2005 that,

"The adjusted net saving gap measures, as a percentage of GNI, the difference between actual ANS and the amount necessary to maintain per capita wealth. The savings gap for the United States and New Zealand is 2 percent."

It is to this issue that we now turn. 
The results from which the above quotes relate, consider a snapshot for the year 2005 . Based upon our measures, and taking an average of the equivalent of their ANS gap as a \% of GNI, we confirm that (an average of the years 2004-2006) produces a gap of $2.11 \%$ for New Zealand (see, Table 5 below which also presents some averages over different periods).

Table 5: Measures of the Average GS Gap as a percentage of GNS

\begin{tabular}{lcc}
\hline Period & Avg. GS Gap (\% GNS) & Avg. GS Gap (\% GNS) WB format \\
\hline $1955-2015$ & $0.5 \%$ & $0.5 \%$ \\
$1970-2015$ & $-9.0 \%$ & NA \\
$1985-2015$ & $-6.4 \%$ & NA \\
$2000-2015$ & $7.2 \%$ & $7.2 \%$ \\
$1955-1975$ & $15.1 \%$ & $15.1 \%$ \\
$1975-1995$ & $-22.7 \%$ & NA \\
$1995-2015$ & $-1.5 \%$ & NA \\
$2004-2006$ & $2.1 \%$ & $2.1 \%$ \\
\hline
\end{tabular}

Positive (negative) number is bad (good) as it shows the country is saving less (more) than required to maintain sustainability. The World Bank (WB) has replaced negative numbers with NA (not applicable) in their estimates.

The results suggest that, over the period 1955-2015, New Zealanders should have saved an average of $0.5 \%$ more to maintain sustainability.

Looking at specific sub-periods, it is interesting to note that New Zealanders actions initially reflected (unsustainably) low savings rates, with the gap narrowing only to start to widen again recently. It is noteworthy that for 2000-2015 the average GS gap as a \% of GNS is $+7.2 \%$, which is second only to $1955-1975$ as a period of a large savings gap. This can perhaps be seen more readily via Figure 8 below. 
Figure 8. Trends in the GS Gap as a percentage of GNS and its 10-year moving average

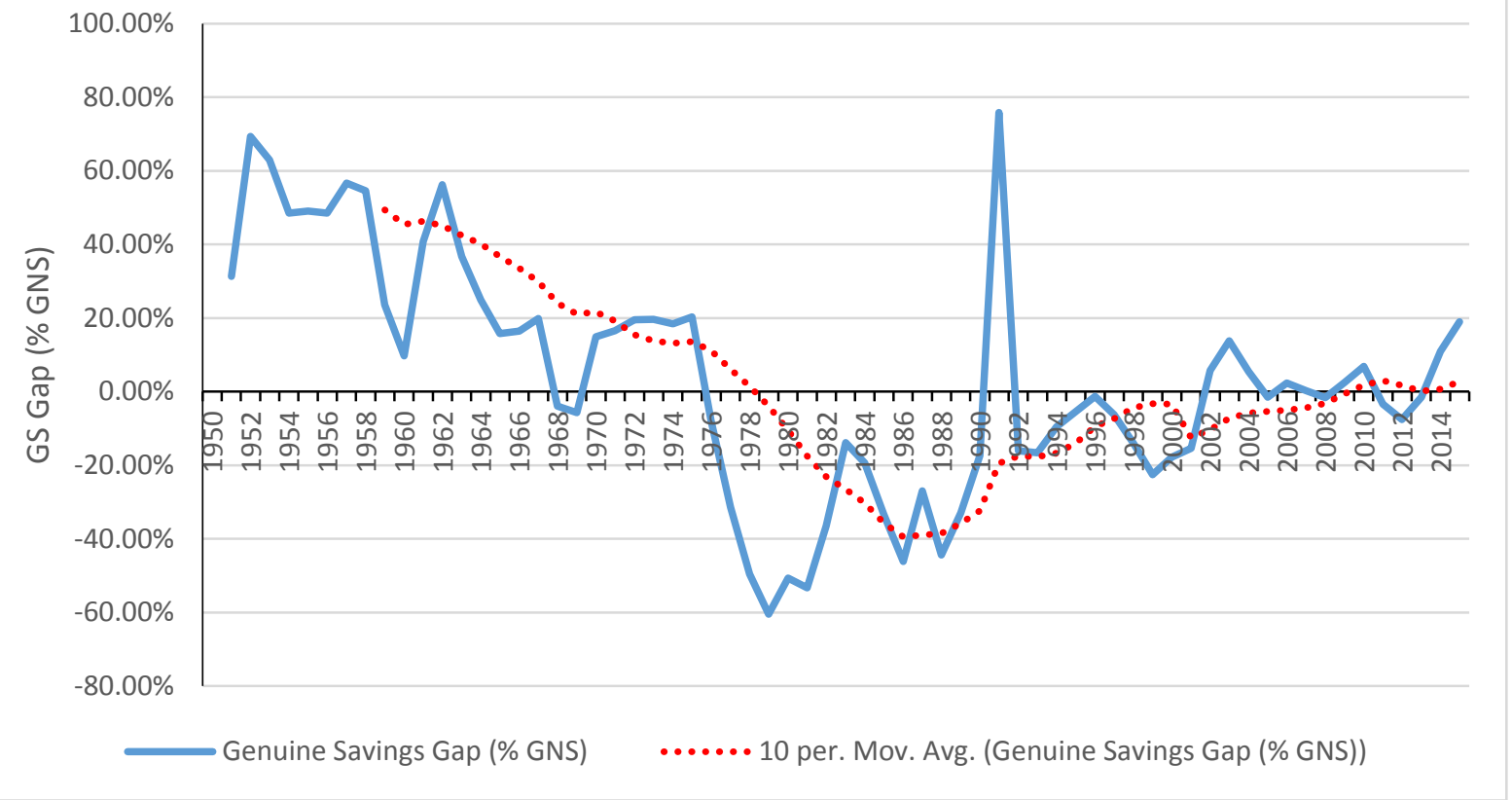

A positive (negative) number is bad (good) as it shows the country is saving less (more) than required to maintain sustainability. Source, Table 5 above.

Table 6: Savings year-on-year percentage changes in capital stocks.

\begin{tabular}{lrrrr} 
Period & $\begin{array}{r}\text { Human } \\
\text { Capital }\end{array}$ & $\begin{array}{r}\text { Fixed } \\
\text { Capital }\end{array}$ & $\begin{array}{r}\text { Non-renewable } \\
\text { natural capital }\end{array}$ & $\begin{array}{r}\text { Renewable } \\
\text { natural capital }\end{array}$ \\
\hline $1950-2015$ & $4.46 \%$ & $3.49 \%$ & $6.53 \%$ & $5.71 \%$ \\
$1960-2015$ & $4.24 \%$ & $3.43 \%$ & $6.61 \%$ & $7.87 \%$ \\
$1970-2015$ & $3.45 \%$ & $2.99 \%$ & $7.78 \%$ & $7.87 \%$ \\
$1980-2015$ & $3.20 \%$ & $2.39 \%$ & $10.16 \%$ & $7.87 \%$ \\
$1990-2015$ & $3.69 \%$ & $2.82 \%$ & $10.12 \%$ & $7.87 \%$ \\
$2000-2015$ & $3.04 \%$ & $2.53 \%$ & $-0.01 \%$ & $7.87 \%$ \\
\hline
\end{tabular}

\subsection{Changes in wealth per capita}

The second element of the World Bank (2010) p.41 \&43, conclusion relates to:

"New Zealand (has) had positive ANS, but a decline in per capita wealth because saving has not been sufficient to compensate for population growth."

For 2005 the World Bank calculates that the changes in wealth per capita was (US\$) -501 .

Using our new dataset and real NZ\$ (discounted) we calculate the following: 
Table 7: Average change in wealth per capita

\begin{tabular}{lrr}
\hline $\begin{array}{l}\text { Time } \\
\text { horizon }\end{array}$ & $\begin{array}{r}\text { Avg. Change in Wealth } \\
\text { per capita }\end{array}$ & $\begin{array}{r}\text { Avg. Change in Wealth per } \\
\text { capita }\end{array}$ \\
\hline $1951-2015$ & (at 1.4\% discount rate) & (at 2.8\% discount rate) \\
$1951-1975$ & -84.65 & -57.90 \\
$1976-2000$ & -1624.22 & -1344.29 \\
$2000-2015$ & 1567.12 & 1304.49 \\
$2003-2007$ & -154.02 & -86.14 \\
\hline
\end{tabular}

Figure 9: Year-on-year change in wealth per capita (2.8\% discount rate)

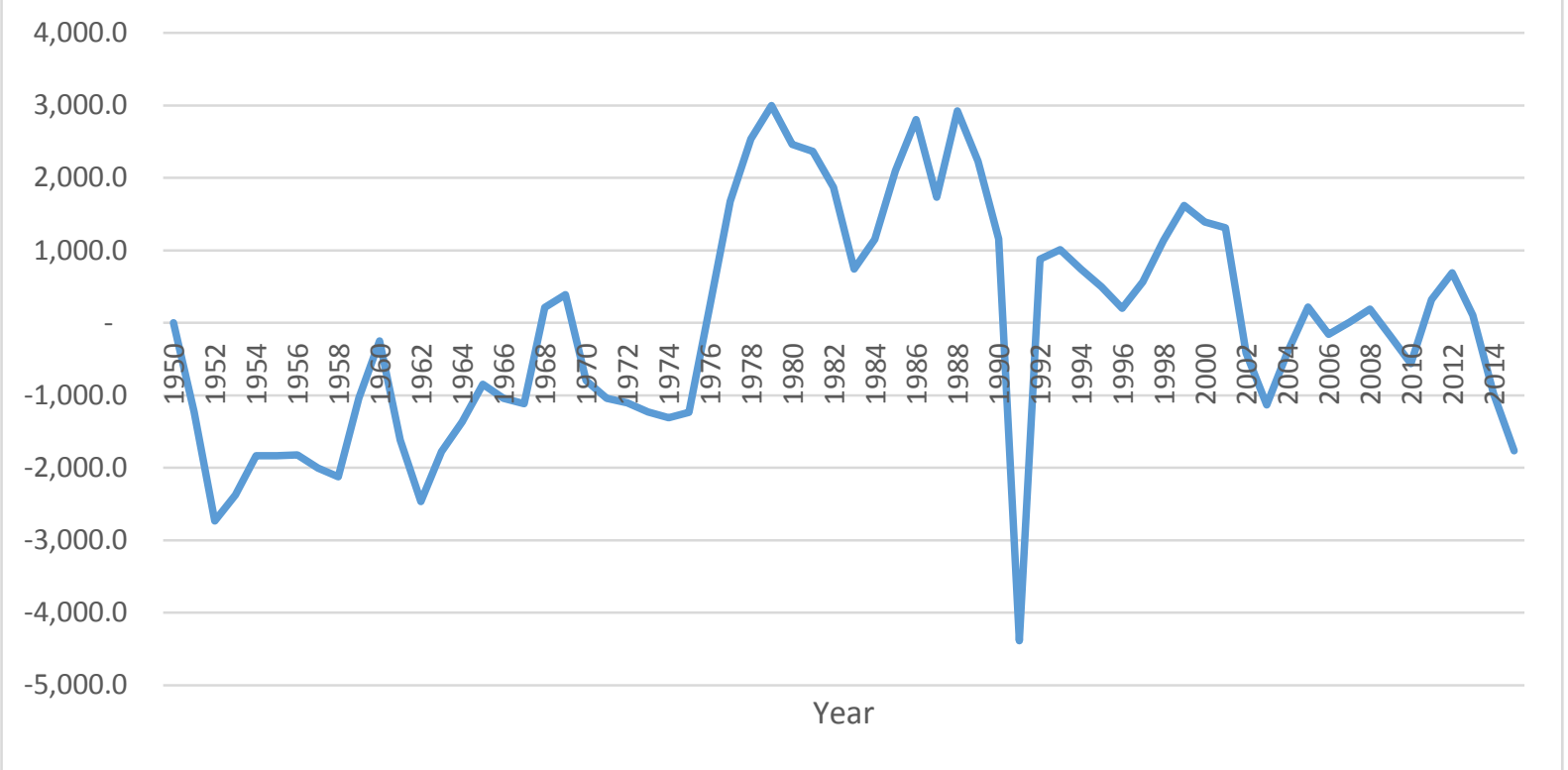

Figure 10: Cumulative change in wealth per capita

$5,000.0$

$-5,000.0$

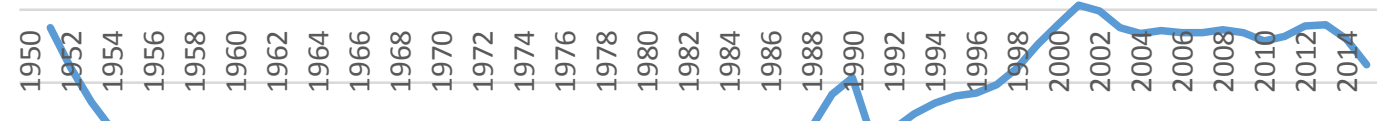

$-10,000.0$

$-15,000.0$

$-20,000.0$

$-25,000.0$

$-30,000.0$

$-35,000.0$

$-40,000.0$

$$
\text { Year }
$$


Compared with the point estimate for 2005 of (undiscounted) (US\$) -501 our average for the period 2003-2007 ranges from (NZ\$) -431 to -295 depending on discount rate. Given the different (expanded) dataset and the effect of discounting we see these two sources providing a similar pattern of declines in wealth per capita. Turning to the whole sample period, Figures 9 and 10 plot the time series of year-on-year changes in wealth per capita and the cumulative share in wealth per capita. Not surprisingly, the two figures reflect the savings-gap reported above, but present it in terms of real NZ\$ per capita.

Although New Zealand remains weakly sustainable throughout the period, the effects of population growth have lead to wealth dilution with. At best, over the new millennium, New Zealand wealth per capita remains static.

\subsection{Contributions from 'the Capitals'.}

Table 6, above, presents a breakdown of the year-on-year percentage change contributions of the various forms of capital. It is interesting to note the steady decline of the contribution from human capital. This is of concern if we are correctly measuring the stock of human capital correctly (via expenditures on education). As noted previously, the extent to which 'brain-gain' by way of immigrant inflows of (NZ unfunded) human capital is not being captured could be an issue, but one might expect this to show-up in the measure of TFP. However, it is well understood (and our data reflect this) that in New Zealand TFP is consistently lower than in other OECD countries.

Contributions from fixed capital also show a declining trend - an issue also well documented in the case of New Zealand. For non-renewable natural capital there was an upward trend until the beginning of the new millennium where for the period 2000-2015 this form of capital appears to be adding nothing to the stock of capital. Combining the information from Tables 5 and 6 we get a finer-grained picture emerging. If we consider the 1970s-1990s, the savings gap is around $-8 \%$ (where negative is good). This gap seems to have been mainly created via the contribution from non-renewable natural capital. This is effectively reversed with a $+7.2 \%$ savings gap, (positive is bad) for the period 2000-2015 when the contribution from non-renewable natural capital is -0.01 per cent. 
The contribution from renewable natural capital has been effectively constant since the 1960s (at 7.87\%).

Overall, therefore, Tables 5 and 6 present some 'good-news, bad-news' stories. On the good news, renewable natural capital (mainly forestry-related) provides consistently the largest contribution to the growth in the capitals. The bad news is that human capital and fixed capital taken together do not even match this contribution from renewable natural capital. On non-renewable natural capital it was singly the largest contributor to the total stock of capital for around 25 years from the mid-1970s to 2000 . Although potentially bad news, in this case it was this type of capital that was contributing most to creating a negative savings gap (a good thing) which was reversed for the period 2000-2015 (where it stands at a large $7.2 \%$ ) as its contribution declined to $-0.1 \%$ and the other capitals (especially human and fixed were unable to pick-up their own growth (in fact they declined in terms of their contributions). In order to reduce the large savings gap (the average GS gap as a percentage of GNS) that now exists, there need to be increasing contributions to total capital. If nonrenewable natural capital is to be protected for e.g., environmental issues, then the other capitals (human, fixed and renewable natural) need to make significant additional contributions from what at the moment appears to be a trend decline.

\subsection{Discussion}

\subsection{Summary}

Genuine Savings has become one of the most popular, and perhaps important, indicators of sustainable development (Bank, 2011, Greasley et al., 2016). This indicator focuses on how well a country maintains its total asset base, i.e. natural capital, human capital and produced capital, over time considering how rents from the depletion of natural resources are utilized for current consumption or savings for the future. It permits discussion and testing of the effects of population growth, which potentially dilutes the amount of capital available to future generations. It also enables measures of savings gaps to be calculated with a view, perhaps to use government policy to close them for the benefit of future generations.

In this paper, we conducted tests of increasingly comprehensive measures of savings as indicators of long-term sustainability for New Zealand. The key contribution of this study has 
been to undertake the first medium/long-run test of the performance of Genuine Savings as an indicator of changes in future well-being in New Zealand. We complied time series data on GS and other comprehensive savings measures, over the period 1950 - 2015 for New Zealand and tested how well they explain changes in future well-being over time.

Key contributions of this study are as follows: Firstly, the estimates of New Zealand Genuine Savings have been constructed for an extended period over 1950-2015 and then tested as to how well they explain changes in future well-being over time. Secondly, these measures of savings have also been extended to augment the value of exogenous technological progress. For two alternative measure of future well-being (real GDP per capita and real consumption per capita), our results align closely with the theoretical relationship between GS and future well-being, and provide strong support for the indicative capacity of the GS model, compared to previously published studies. Thirdly, changes in future well-being measures have been measured over different time horizons $\left(10,15,20\right.$ and $30^{7}$ years).

Given the length of data series, we found the empirical relationship between well-being measures and comprehensive savings exhibits non-linear patterns relative to the future time horizons used to calculate discounted values for example, this relationship is insignificant at 10 year time horizons; it becomes significant or increasingly significant for 20 years and then insigniciant thereafter. These results reinforce the need to advance technologically to attain higher productivity so that the impact to technology becomes significantly visible in the shorter time spans.

New Zealand's GS as reported here has been positive since the start of our data series even without allowing for a value of technological advancement ${ }^{8}$. The average GS to GDP ratio as reported here has been around $17 \%$, which is sufficient to meet the generalized "Hartwick" rule over time suggested by Hamilton \& Hartwick (2005b). However, New Zealand's real consumption per capita has been growing at a much lower rate of about $1.5 \%$ for the same

\footnotetext{
${ }^{7}$ See Appendix for detailed results

${ }^{8}$ However, as the World Bank (2011), p43, concludes: "Even developed countries such as the United States and New Zealand have had positive ANS but a decline in per capita wealth because saving has not been sufficient to compensate for population growth."
} 
period. This suggests New Zealand has maintained higher levels of genuine savings ${ }^{9}$ compared to those of for example, Australia, which has an average growth rate of saving of $5 \%$ with a similar growth rate in consumption (Greasley et al., 2016) ${ }^{10}$.

We have also calculated i) the effects of wealth-dilution (e.g. of a growing population having less capital available to them) and ii) an average GS gap as a percentage of GNS and iii) the contributions to total capital wealth arising from the four capitals (human, fixed, nonrenewable natural and renewable natural capital).

Although over the period of study, New Zealand has consistently satisfied the criteria for weak sustainability (with GS throughout being positive), there are periods (including all of this millennium) where a savings gap exists with wealth dilution also putting some strain of sustainable development.

The key discussion here around the utility of GS as an indicator of weak sustainability raises the possibility that the non-renewable natural resource depletion is understated in empirical estimates. For example, Brown, Asafu-Adjaye, Draca, \& Straton (2005) have shown that coral and water resources degradation may not be reflected in the estimates. Although we included the rents from the mining of all natural resources available from national statistical office in our estimates, historical data constructed here may not include all changes in natural capital. Without allowing a value of technological advances, measures of comprehensive savings slightly understate the PV value of future well-being measures, and including technology augmented measures of savings explain changes very closely.

\subsection{Some potential government policy-related issues to consider}

\subsubsection{Issues}

The results from the paper suggest that over the period 1950-2015, New Zealand:

- Has exhibited positive GS from which we can infer that the economic data is consistent with being on a weakly sustainable development path

\footnotetext{
${ }^{9}$ The World Bank (2011), p41., concludes that: "The adjusted net saving gap measures, as a percentage of GNI, the difference between actual ANS and the amount necessary to maintain per capita wealth. The savings gap for the United States and New Zealand is 2 percent."

10 "For example, a detailed analysis of human capital accounts for Canada, New Zealand, Norway, Sweden, and the United States unambiguously shows that human capital is a leading source of economic growth." World Bank (2011), p105. This conclusion, however, is based upon the exclusion of all forestry related measures of capital from the World Bank estimates.
} 
- Has experienced an average GS to GDP ratio of approximately $17 \%$, which is sufficient to meet the generalized "Hartwick" rule over time suggested by Hamilton \& Hartwick (2005b).

- Has a rate of technological progress (as measured by TFP), which has contributed less to explaining measures of future wellbeing than in similar developed economics for example, Australia, Germany, Britain and the USA.

- Has experienced savings gaps (where positive is bad and negative good), which have varied over the period, with the decade $2000-2010$ exhibiting a $+7.2 \%$ average GS gap as a percentage of GNS.

- Exhibits a situation where wealth dilution effects are important and will put further strain on sustainable development if population growth rates continue at comparatively high levels, unless the stock of capitals increases at a rate faster than experienced in the past 65 years ${ }^{11}$.

- Has experienced year-on-year increases in human, fixed and renewable natural capital assets that are internationally comparatively low (and typically declining) leaving, until very recently, non-renewable natural capital growth rates to reduce the savings gap. Moving into a period where non-renewable natural capital growth rates are now stagnant (or declining), will put the onus on the other capitals to grow at historically unprecedented levels in order to seek to achieve future positive changes in wealth per capita.

- In terms of wealth per capita, wealth dilution has been the typical pattern to emerge from the beginning of the sample through to the early 1990s, created, in the main, by a persistent GS/NNS savings gap. This gap is beginning to re-emerge in the new millennium, where for the period $2000-2010$ it was (on average) $+7.2 \%$. This is reflected in changes in wealth per capita of between $\$-431$ and $\$-295$.

\subsubsection{Policy}

- Although the data suggest that the necessary conditions for weak sustainability and the Hartwick Rule are being satisfied in New Zealand, there are issues of concern in terms of long term sustainable development in particular:

\footnotetext{
${ }^{11}$ This assumes we are measuring brain-gain human capital from migration sufficiently accurately.
} 
- Changes in per capita wealth have been declining due to the effects of savings gaps and wealth-dilution

- Savings gaps have re-emerged in New Zealand (they were more persistent and higher in the early parts of the sample than in the new millennium) in part because of:

- Relatively small effects from technological change when applied to the stocks of capital in relation to maintaining and/or increasing future wellbeing

- Low and downward trending additions to stocks of human ${ }^{12}$ and fixed capital; stagnant growth rates in the stocks of renewable natural capital.

- Non-renewable natural capital was the area with the highest growth rates, which in part was reversing the savings gaps in the 1980s, and '90s. However, this reversed in the new millennium leading to a $7.2 \%$ savings gap. The challenge here is to increase the growth rates of the other capitals (particularly human) to compensate for the decline in the growth of non-renewable natural capital exploitation, which is likely to encounter longer-term environmental resistance.

- Including forestry (standing timber) in measures of GS leads to positive increases in future wellbeing and likely positive changes in per capita wealth.

- More land dedicated to forestry will increase the stock of renewable natural capital with positive carbon sink effects, but there may be tensions regarding optimal harvesting rates. Furthermore, the opportunity cost to increasing forest area by planting native forest (which cannot be harvested by law) would likely be significant and may might impact on the future growth of other capitals, for example, produced capital.

- The shift to more dairy farms using marginal lands puts pressures on the expansion of forestry.

\footnotetext{
12 For example, a detailed analysis of human capital accounts for Canada, New Zealand, Norway, Sweden, and the United States unambiguously shows that human capital is a leading source of economic growth." World Bank (2011), p105
} 
- The net contributions to future wellbeing and wealth per capita arising from valuing water effects have yet to be fully evaluated.

- The net contributions to future wellbeing and wealth per capita arising from fishery related effects have yet to be fully evaluated, although the WB is confident the rents from fisheries in New Zealand are likely to be 'substantial'13.

- If/when the effects of emissions (other than $\mathrm{CO}_{2}$ ) are monetised, conclusions relating to sustainable development paths may need to be revised. To some extent, the substitution forestry for other agricultural land may mitigate some of these (likely to be unambiguously negative) effects. However, this is likely to have short-term effects on GDP per capita and consumption per capita growth rates.

\subsection{Some caveats and potentially fruitful areas for further research}

This is only the second ${ }^{14}$, formal, piece of research applying GS-type approaches to New Zealand data. In this paper we extend the sample period and include the contribution made by forestry to renewable natural capital.

However, the work in this area remains 'in progress'. Below we identify some of the important caveats to consider when reading both the detailed results and also e.g., policyrelated implications.

1. We have made some progress, compared to the WB, by including the value of forests (standing timber) in New Zealand and by extending the sample period, which is crucially important for GS-type approaches. Forests make little or no contribution to natural capital in the countries considered by Greasley et. al., (2017), but are significant in the case of New Zealand. In our results here, the inclusion of renewable natural capital (like forests) is important when calculating GS (without augmentation by TFP) where its contribution is relatively large in New Zealand.

\footnotetext{
13 "There are notable exceptions to this, such as fisheries in Iceland, New Zealand, and Namibia, where better management allows substantial rents to be generated" World Bank (2011), p.21

${ }^{14}$ World Bank (2011)
} 
2. Although we have included an estimate of the value of standing timber, we have not sought to calculate the positive effects forests have such as carbon sinking, soil stabilization, water purification, climate regulation etc. This would no doubt increase the value of forestry (and other similar types of renewable natural capital) within this framework.

3. We have not calculated the effects of shifting land-use patterns, e.g., the reduction in land used for forestry as dairy farming moves into more marginal land.

4. We have not calculated the costs associated with GHG emissions, which other authors have sought to include in their GS models. Although there are good models (and international prices) for $\mathrm{CO}_{2}$, which may be a positive (net) contribution for New Zealand, the same is not the case for other emissions e.g., methane. Such work would be important future work.

5. The economic value of fisheries has not been included. Work by the WB suggests that fisheries in New Zealand are likely to be positive ${ }^{15}$. Further work in this area would be an important future development of this programme of research ${ }^{16}$.

6. Similarly, the contributions and costs of water-related natural capital have not been included.

7. Health related costs (again something some authors have tried to quantify in their GS-related work) have not been calculated or included in this paper.

8. Potential non-marketed values of natural capital (or social or cultural capital) have not been calculated.

9. Technological progress has proven to be an important element in terms of trying to explain the roles various forms of capital have on future wellbeing. Total final productivity is often the 'go-to' measure of progress, although it is not without its critics. In this paper we use the TFP estimates from Greasley and Madsen (2016) and the extent to which they are a 'good' measure for New Zealand is something we have not considered. It certainly seems that technological progress seems to contribute less to our GS estimates than in other countries where the GS approach has been

\footnotetext{
15 "There are notable exceptions to this, such as fisheries in Iceland, New Zealand, and Namibia, where better management allows substantial rents to be generated" World Bank (2011), p.21.

16 "New Zealand introduced a system of individually tradable quotas to manage its fisheries, resulting in a large competitive market for fish quota sales and rentals. This system has established a direct market price for the asset value of fisheries, which is used in the New Zealand fisheries accounts. "World Bank (2011) p. 135.
} 
implemented (see Greasley et. al. 2016), however, this conclusion does not seem to be out of line with other commentary on New Zealand's (low) productivity performance over the period.

10. Human capital is an important element in the GS-sustainability story. Ultimately, all other forms of capital are finite and it is this element, which perhaps holds the key to sustainable development at least cost to the other capitals. Here we measure human capital via its expenditure cost. This is a relatively crude (though not uncommon) way to measure the growth in human capital and other options are available (see Le et al. (2003). However, to date these alternative (better) measures have not been extensively applied to New Zealand data and would be another area where fruitful futures research could be undertaken. This may lead to a more positive prognosis for the contributions human capital has (and could have) on the growth of total wealth.

11. Overall, therefore, it is hard to speculate what the net effect of including and resolving caveats 2-10 would be for calculations of for example, GS, savings gaps, wealth dilution and ultimately long-term sustainability in the case of New Zealand. In this paper we have provided a detailed framework of i) the GS approach; ii) the data demands and iii) some preliminary results. Future work should be able to build on these foundations to get a clearer and more detailed picture to inform for example, policy advice and actions to identify, and potentially steer or nudge the economy to sustainable development

paths. 


\section{References}

Arrow, K. J., Dasgupta, P., Goulder, L. H., Mumford, K. J. \& Oleson, K. (2012). Sustainability and the measurement of wealth. Environment and Development Economics, 17(03), 317-353. doi:10.1017/S1355770X12000137

Asheim, G. B. (1994). Net National Product as an Indicator of Sustainability. The Scandinavian Journal of Economics, 96(2), 257-265. Retrieved from http://www.jstor.org/stable/3440603

Bank, W. (2011). The Changing Wealth of Nations: Retrieved from https://openknowledge.worldbank.org/handle/10986/2252

Black, S. E. \& Lynch, L. M. (1996). Human-capital investments and productivity. The American economic review, 86(2), 263-267. JSTOR.

Blattman, C., Hwang, J. \& Williamson, J. G. (2007). Winners and losers in the commodity lottery: The impact of terms of trade growth and volatility in the Periphery 18701939. Journal of Development economics, 82(1), 156-179. Elsevier.

Blum, M., Ducoing, C. \& McLaughlin, E. (2017a). A Sustainable Century? Genuine Savings in developing and developed countries, 1900-2000. National Wealth: what is missing, why it matters. Oxford University Press.

Blum, M., McLaughlin, E. \& Hanley, N. (2017b). Accounting for sustainable development over the long-run: lessons from Germany, 1850-2000. German Economic Review. DOI: 10.1111/geer.12148

Blundell, R., Dearden, L., Meghir, C. \& Sianesi, B. (1999). Human capital investment: the returns from education and training to the individual, the firm and the economy. Fiscal studies, 20(1), 1-23. Wiley Online Library.

Bolt, K., Matete, M. \& Clemens, M. (2002). Manual for calculating adjusted net savings. Environment Department, World Bank, 1-23.

Brown, R. P. C., Asafu-Adjaye, J., Draca, M. \& Straton, A. (2005). How Useful Is the Genuine Savings Rate as a Sustainability Indicator for Regions within Countries? Australia 
and Queensland Compared. Australian Economic Review, 38(4), 370-388. Blackwell Publishing Ltd. doi:10.1111/j.1467-8462.2005.00381.x

Dasgupta, P. (2001). Human well-being and the natural environment. Oxford University Press.

Dasgupta, P. \& Heal, G. (1974). The Optimal Depletion of Exhaustible Resources. The Review of Economic Studies, 41, pp. 3-28. Oxford University Press. Retrieved from http://www.jstor.org/stable/2296369

Dasgupta, P. \& Mäler, K.-G. (2001). Wealth as a criterion for sustainable development. Citeseer.

Dietz, S. \& Neumayer, E. (2007). Weak and strong sustainability in the SEEA: Concepts and measurement. Ecological Economics, 61(4), 617 - 626. doi:http://dx.doi.org/10.1016/j.ecolecon.2006.09.007

Elliott, G., Rothenberg, T. J. \& Stock, J. H. (1992). Efficient tests for an autoregressive unit root. National Bureau of Economic Research Cambridge, Mass., USA.

Engle, R. F. \& Granger, C. W. (1987). Co-integration and error correction: representation, estimation, and testing. Econometrica: journal of the Econometric Society, 251-276.

Fagerberg, J. (2000). Technological progress, structural change and productivity growth: a comparative study. Structural change and economic dynamics, 11(4), 393-411. Elsevier.

Färe, R., Grosskopf, S. \& Margaritis, D. (2001). Productivity trends in Australian and New Zealand manufacturing. Australian Economic Review, 34(2), 125-134. Wiley Online Library.

Fenichel, E.P., and Abbott, J.K. (2014). Natural Capital: From Metaphor to Measurement, Journal of the Association of Environmental and Resource Economists, 1,1, 1-27.

Ferreira, S., Hamilton, K. \& Vincent, J. R. (2008). Comprehensive Wealth and Future Consumption: Accounting for Population Growth. World Bank Economic Review, 22(2), 233-248. doi:10.1093/wber/Ihn008 
Ferreira, S. \& Vincent, J. R. (2005). Genuine Savings: Leading Indicator of Sustainable Development? Economic Development and Cultural Change, 53(3), 737-754. The University of Chicago Press. Retrieved from http://www.jstor.org/stable/10.1086/426834

Ferreira, S. and Moro, M. (2011). Constructing genuine savings indicators for Ireland, 19952005. Journal of Environmental Management. 92, 542-53.

Gemmell, N. (1996). Evaluating the impacts of human capital stocks and accumulation on economic growth: some new evidence. Oxford bulletin of economics and statistics, 58(1), 9-28.

Glass, H., Choy, W. K. \& others. (2001). Brain drain or brain exchange?

Greasley, D., Hanley, N., Kunnas, J., McLaughlin, E., Oxley, L. \& Warde, P. (2014). Testing genuine savings as a forward-looking indicator of future well-being over the (very) long-run . Journal of Environmental Economics and Management, 67(2), 171 - 188. doi:http://dx.doi.org/10.1016/j.jeem.2013.12.001

Greasley, D., Hanley, N., McLaughlin, E. \& Oxley, L. (2017). Australia: a Land of Missed Opportunities? Environment and Development Economics , 22, 674-98.

Greasley, D. \& Madsen, J. B. (2016). The rise and fall of exceptional Australian Incomes since 1800. Australian Economic History Review. Wiley Online Library.

Greasley, D. \& Oxley, L. (2010). Cliometrics and time series econometrics: some theory and applications. Journal of Economic Surveys, 24(5), 970-1042.

Hamilton, K. (1994). Green adjustments to GDP. Resources Policy , 20(3), 155 - 168. doi:http://dx.doi.org/10.1016/0301-4207(94)90048-5

Hamilton, K. (2006). Where is the wealth of nations?: measuring capital for the 21st century. World Bank Publications.

Hamilton, K. \& Atkinson, G. (2006). Wealth, welfare and sustainability: Advances in measuring sustainable development. Edward Elgar Publishing. 
Hamilton, K. \& Clemens, M. (1999). Genuine Savings Rates in Developing Countries. World Bank Economic Review, 13(2), 333-356. doi:10.1093/wber/13.2.333

Hamilton, K. \& Hartwick, J. M. (2005). Investing exhaustible resource rents and the path of consumption. Canadian Journal of Economics, 38(2), 615 - 621. Retrieved from http://search.ebscohost.com.ezproxy.waikato.ac.nz/login.aspx?direct=true \&db=bt h\&AN=16599915\&site=ehost-live

Hamilton, K. \& Hartwick, J. M. (2005). Investing exhaustible resource rents and the path of consumption. Canadian Journal of Economics/Revue canadienne d'économique, 38(2), 615-621. Wiley Online Library.

Hanley, N., Dupuy, L. \& McLaughlin, E. (2015). Genuine Savings and sustainability. Journal of Economic Surveys, 29(4), 779-806. doi:10.1111/joes.12120

Hanley, N., Oxley, L., Greasley, D. M. E. \& Blum, M. (2016). Empirical Testing of Genuine Savings as an Indicator of Weak Sustainability: A Three-Country Analysis of LongRun Trends. Environmental and Resource Economics, 63(2), 313-338. doi:10.1007/s10640-015-9928-7

Hartwick, J. M. (1977). Intergenerational equity and the investing of rents from exhaustible resources. American Economic Review, 67(5), 972-974.

Hartwick, J. M. (1990). Natural resources, national accounting and economic depreciation. Journal of Public Economics, 43(3), 291 - 304. doi:http://dx.doi.org/10.1016/00472727(90)90002-Y

Hicks, J. R. (1946). Value and Capital: An Inquiry Into Some Fundamental Principles of Economic Theory. Oxford: Clarendon Press.

Hollinger, D., Maclaren, J., Beets, P. \& Turland, J. (1993). Carbon sequestration by New Zealand's plantation forests. New Zealand Journal of Forestry Science, 23(2), 194208. Citeseer.

Homer, S. \& Sylla, R. (2005). A History of Interest Rates. Wiley Finance. Wiley. Retrieved from https://books.google.co.nz/books?id=OOQKf4asZ9EC 
Le, T., Oxley, L. and Gibson, J. (2003). Cost- and Income-Based Measures of Human Capital, Journal of Economic Surveys, 17, 271-308.

Lindmark, M., Thu, H. N. \& Stage, J. (2018). Weak support for weak sustainability: Genuine savings and long-term wellbeing in Sweden, 1850-2000. Ecological Economics, 145, 339 345. doi:https://doi.org/10.1016/j.ecolecon.2017.11.015

Mota, R. P., D. T. and Martins, V. (2010). Analysis of genuine savings and potential net national income:Portugal, 1990-2005. Ecological Economics 69, 1934-1942.

Mota, R. P. and Domingos, T. (2013), 'Assessment of the theory of comprehensive national accounting with data for Portugal'. Ecological Economics 95, 188-196.

Neumayer, E. (2010), Weak Versus Strong Sustainability: Exploring

NZIER. (2017). Plantation forestry statistics: Contribution of forestry to New Zealand.

Oxley, L. (2017), Sustainable Economic Development: Origins, Concepts, Models and Metrics, Working Paper, University of Waikato.

Pearce, D. W. \& Atkinson, G. D. (1993). Capital Theory and the Measurement of Sustainable Development: An Indicator of Weak Sustainability . Ecological Economics , 8(2), 103 - 108. doi:http://dx.doi.org/10.1016/0921-8009(93)90039-9

Pearce, D. W., Markandya, A. \& Barbier, E. (1989). Blueprint for a green economy (Vol. 1). Earthscan.

Pemberton, M. \& Ulph, D. (2001). Measuring income and measuring sustainability. The Scandinavian Journal of Economics, 103(1), 25-40. Wiley Online Library.

Pezzey, J. C. V. (2004). One-sided sustainability tests with amenities, and changes in technology, trade and population. Journal of Environmental Economics and Management , 48(1), 613 - 631. doi:http://dx.doi.org/10.1016/j.jeem.2003.10.002

Pezzey, J. C. V., Hanley, N., Turner, K. \& Tinch, D. (2006). Comparing augmented sustainability measures for Scotland: Is there a mismatch? . Ecological Economics, 57(1), 60 - 74. doi:http://dx.doi.org/10.1016/j.ecolecon.2005.03.006 
Qasim, M. (2017). Sustainability and wellbeing: A scientometric and bibliometric review of the literature. Journal of Economic Surveys, 31(4), 1035-1061.

Quiggin, J. (1997). Discount rates and sustainability. International Journal of Social Economics, 24(1/2/3), 65-90. MCB UP Ltd.

Romero, J. C. \& Linares, P. (2014). Exergy as a global energy sustainability indicator. A review of the state of the art . Renewable and Sustainable Energy Reviews , 33(0), 427 - 442. doi:http://dx.doi.org/10.1016/j.rser.2014.02.012

Solow, R. M. (1974). The Economics of Resources or the Resources of Economics. The American Economic Review, 64(2), pp. 1-14. American Economic Association. Retrieved from http://www.jstor.org/stable/1816009

Tate, K., Scott, N., Parshotam, A., Brown, L., Wilde, R., Giltrap, D., Trustrum, N., et al. (2000). A multi-scale analysis of a terrestrial carbon budget: is New Zealand a source or sink of carbon? Agriculture, ecosystems \& environment, 82(1), 229-246. Elsevier.

UNU-IHDP and UNEP (2012). Inclusive Wealth Report 2012: Measuring Progress toward sustainability. Cambridge: Cambridge University Press.

UNU-IHDP and UNEP (2014). Inclusive Wealth Report 2014. Measuring progress toward sustainability. Cambridge: Cambridge University Press.

Weitzman, M. L. (1997). Sustainability and technical progress. The Scandinavian Journal of Economics, 99(1), 1-13. Wiley Online Library.

World Bank (2006). Where is the Wealth of Nations?: Measuring capital for the $21^{\text {st }}$ Century. The International Bank for Reconstruction and Development / The World Bank, Washington, DC.

World Bank (2011). The Changing Wealth of Nations: Measuring Sustainable Development in the New Millennium, The International Bank for Reconstruction and Development / The World Bank, Washington, DC. 
World Bank (2018). The Changing Wealth of Nations 2018: Building a Sustainable Future.

The International Bank for Reconstruction and Development / The World Bank, Washington, DC. 


\section{Appendix}

Table 2A: Comparison of the World Bank and New Zealand national statistics office data sources

\begin{tabular}{|c|c|c|c|c|}
\hline Variable & World Bank Definition & World Bank Data Sources & Stat NZ Definition & Data Source \\
\hline Population & $\begin{array}{l}\text { Series Code: SP.POP.TOTL } \\
\text { The total population is based on the de facto } \\
\text { definition of population, which counts all } \\
\text { residents regardless of legal status or } \\
\text { citizenship--except for refugees not } \\
\text { permanently settled in the country of asylum, } \\
\text { who are generally considered part of the } \\
\text { population of their country of origin. The values } \\
\text { shown are midyear estimates. }\end{array}$ & $\begin{array}{l}\text { (1) United Nations Population Division. } \\
\text { World Population Prospects, (2) United } \\
\text { Nations Statistical Division. Population } \\
\text { and Vital Statistics Report (various } \\
\text { years), (3) Census reports and other } \\
\text { statistical publications from national } \\
\text { statistical offices, (4) Eurostat: } \\
\text { Demographic Statistics, (5) Secretariat } \\
\text { of the Pacific Community: Statistics and } \\
\text { Demography Programme, and (6) U.S. } \\
\text { Census Bureau: International Database. }\end{array}$ & $\begin{array}{l}\text { Population (Est.) Mean } \\
\text { for year ended } 31 \\
\text { December }\end{array}$ & $\begin{array}{l}\text { The New Zealand } \\
\text { Official Yearbooks } \\
\text { and Stat NZ } \\
\text { InfoShare }\end{array}$ \\
\hline GDP (nominal) & $\begin{array}{l}\text { Series Code: NY.GDP.MKTP.CN } \\
\text { GDP at purchaser's prices is the sum of gross } \\
\text { value added by all resident producers in the } \\
\text { economy plus any product taxes and minus any } \\
\text { subsidies not included in the value of the } \\
\text { products. It is calculated without making } \\
\text { deductions for depreciation of fabricated assets } \\
\text { or for depletion and degradation of natural } \\
\text { resources. Data are in current local currency. }\end{array}$ & $\begin{array}{l}\text { World Bank national accounts data, and } \\
\text { OECD National Accounts data files. }\end{array}$ & $\begin{array}{lr}\text { Gross } & \text { Domestic } \\
\text { Product - expenditure } \\
\text { measure } \\
\text { Nominal actual } \\
\text { aggregates (Annual- } \\
\text { March) in NZD }\end{array}$ & $\begin{array}{l}\text { The New Zealand } \\
\text { Official Yearbooks } \\
\text { and Stat NZ } \\
\text { InfoShare }\end{array}$ \\
\hline GDP & $\begin{array}{l}\text { Series Code: NY.GDP.MKTP.KN } \\
\text { GDP is the sum of gross value added by all } \\
\text { resident producers in the economy plus any } \\
\text { product taxes and minus any subsidies not } \\
\text { included in the value of the products. It is } \\
\text { calculated without making deductions for } \\
\text { depreciation of fabricated assets or for } \\
\text { depletion and degradation of natural resources. } \\
\text { Data are in constant local currency. }\end{array}$ & $\begin{array}{l}\text { World Bank national accounts data, and } \\
\text { OECD National Accounts data files. }\end{array}$ & $\begin{array}{l}\text { Price deflator gross } \\
\text { domestic product - } \\
\text { (National currency: } \\
2010=100 \text { ) - New } \\
\text { Zealand estimated } \\
\text { from Retail Price Index } \\
\text { and Consumer Price } \\
\text { Index }\end{array}$ & $\begin{array}{l}\text { The New Zealand } \\
\text { Official Yearbooks } \\
\text { and Stat NZ } \\
\text { InfoShare }\end{array}$ \\
\hline $\begin{array}{l}\text { Education } \\
\text { Expenditure }\end{array}$ & $\begin{array}{l}\text { Series Code: NY.ADJ.AEDU.CD } \\
\text { Education expenditure refers to the current } \\
\text { operating expenditures in education, including } \\
\text { wages and salaries and excluding capital } \\
\text { investments in buildings and equipment. }\end{array}$ & $\begin{array}{l}\text { World Bank staff estimates using data } \\
\text { from the United Nations Statistics } \\
\text { Division's Statistical Yearbook, and the } \\
\text { UNESCO Institute for Statistics online } \\
\text { database. }\end{array}$ & $\begin{array}{l}\text { Government } \\
\text { expenditure on } \\
\text { education } \\
\text { Actual aggregates } \\
\text { (Annual-March) in NZD } \\
\end{array}$ & $\begin{array}{l}\text { The New Zealand } \\
\text { Official Yearbooks } \\
\text { and Stat NZ } \\
\text { InfoShare }\end{array}$ \\
\hline Forestry & NO DATA FROM WB & & & \\
\hline $\begin{array}{l}\text { Energy and } \\
\text { Minerals }\end{array}$ & $\begin{array}{l}\text { Series Code: NY.ADJ.DNGY.CD } \\
\text { Energy depletion is the ratio of the value of the } \\
\text { stock of energy resources to the remaining } \\
\text { reserve lifetime (capped at } 25 \text { years). It covers } \\
\text { coal, crude oil, and natural gas. } \\
\text { Series Code: NY.ADJ.DMIN.CD } \\
\text { Mineral depletion is the ratio of the value of the } \\
\text { stock of mineral resources to the remaining } \\
\text { reserve lifetime (capped at } 25 \text { years). It covers } \\
\text { tin, gold, lead, zinc, iron, copper, nickel, silver, } \\
\text { bauxite, and phosphate. }\end{array}$ & $\begin{array}{l}\text { World Bank staff estimates based on } \\
\text { sources and methods in World Bank's } \\
\text { "The Changing Wealth of Nations: } \\
\text { Measuring Sustainable Development in } \\
\text { the New Millennium" (2011). }\end{array}$ & $\begin{array}{l}\text { Nominal aggregate } \\
\text { value from the } \\
\text { production of metals, } \\
\text { minerals and energy } \\
\text { less production cost in } \\
\text { NZD }\end{array}$ & $\begin{array}{l}\text { The New Zealand } \\
\text { Official Yearbooks } \\
\text { and Stats published } \\
\text { by New Zealand } \\
\text { Petroleum and } \\
\text { Minerals (Ministry of } \\
\text { Business, Innovation } \\
\text { and Employment) }\end{array}$ \\
\hline $\begin{array}{l}\text { Net National } \\
\text { Savings (NNS) }\end{array}$ & $\begin{array}{l}\text { Series Code: NY.ADJ.NNAT.CD } \\
\text { Net national savings are equal to gross national } \\
\text { savings less the value of consumption of fixed } \\
\text { capital. }\end{array}$ & $\begin{array}{l}\text { World Bank staff estimates based on } \\
\text { sources and methods in World Bank's } \\
\text { "The Changing Wealth of Nations: } \\
\text { Measuring Sustainable Development in } \\
\text { the New Millennium" (2011). }\end{array}$ & $\begin{array}{l}\text { NNS }=\text { GNS - } \\
\text { Consumption of fixed } \\
\text { capital }\end{array}$ & \\
\hline $\begin{array}{l}\text { Gross National } \\
\text { Savings (GNS) }\end{array}$ & $\begin{array}{l}\text { Series Code: NY.ADJ.ICTR.GN.ZS } \\
\text { Gross savings are the difference between gross } \\
\text { national income and public and private } \\
\text { consumption, plus net current transfers. }\end{array}$ & $\begin{array}{l}\text { World Bank national accounts data } \\
\text { files. }\end{array}$ & $\begin{array}{l}\text { Gross national savings } \\
\text { are calculated as Gross } \\
\text { Fixed Capital } \\
\text { Formation + Change in } \\
\text { inventory } \\
\text { (Annual-March) in NZD }\end{array}$ & $\begin{array}{l}\text { The New Zealand } \\
\text { Official Yearbooks } \\
\text { and Stat NZ } \\
\text { InfoShare }\end{array}$ \\
\hline $\begin{array}{l}\text { Consumption } \\
\text { of fixed capital }\end{array}$ & $\begin{array}{l}\text { Series Code: NY.ADJ.DKAP.CD } \\
\text { Consumption of fixed capital represents the } \\
\text { replacement value of capital used up in the } \\
\text { process of production. }\end{array}$ & $\begin{array}{l}\text { World Bank staff estimates using data } \\
\text { from the United Nations Statistics } \\
\text { Division's National Accounts Statistics. }\end{array}$ & $\begin{array}{l}\text { Consumption of Fixed } \\
\text { Capital (Annual-March) } \\
\text { in NZD }\end{array}$ & $\begin{array}{l}\text { The New Zealand } \\
\text { Official Yearbooks } \\
\text { and Stat NZ } \\
\text { InfoShare }\end{array}$ \\
\hline
\end{tabular}


In addition to the data series mentioned in the above table, detailed description on the compilation of the other data series is as follows:

\section{Consumption, GDP and GDP deflator:}

Total public and private consumption in real per capita terms is calculated as a residual from GDP. Similarly, all other data series to conduct hypothesis testing are constructed in real per capita terms.

Data source: The New Zealand Official Yearbooks, NZOYBs hereafter, $(1950-1971)$ and Stats NZ (1972 - 2015).

\section{Population:}

Estimated mean population of New Zealand for year ended 31 December.

Data source: NZOYBs (1950 - 1971) and Stats NZ (1972 - 2015).

\section{Education expenditure:}

Human capital is used as a proxy of human capital. This is given by the Total government expenditure on education (including primary, secondary, tertiary etc.) and salaries excluding capital expenditure.

Data source: NZOYBs (1950 - 1971) and Stats NZ (1972 - 2015).

\section{Discount rates:}

We derived discount rates from the mean of bonds long-term series from Homer \& Sylla (2005). We subtracted the percentage of GDP deflator from the bond percentage to get the real discount factor, which is $1.4 \%$ per year. We also use an alternative discount rate of $2.8 \%$ for sensitivity analysis.

\section{Gross national savings (GNS):}

GNS is calculated by subtracting public and private consumption from gross national income plus net exports.

Data source: NZOYBs (1950 - 1971) and Stats NZ (1972 - 2015).

\section{Depreciation of fixed capital:}

It is the replacement value of capital used in the process of production and consumption. Pre-calculated data series for depreciation of fixed capital are given Stats NZ.

\section{Net national savings (NNS):}

It is the difference between GNS and depreciation of fixed capita.

\section{Rents from natural capital (excluding forestry):}

Rents from the mining of natural resources are given by:

Rents $=$ production volume $\times$ unit resource rent

Unit resource rent $=$ unit price - cost of production 
Cost of production $=$ labour emplpyed $\times$ average salaries

In our dataset, the market value of all mineral resources is obtained from NZOYBs (1950 1993), and from the Mining Production Statistics annual publications by the Ministry of Business Innovation and Employment (2000 - 2015). Missing data between these periods is imputed from linear extrapolations.

Data for total labour employed in the mining sector and average annual wage in the mining industry are also compiled from NZOYBs and Stats NZ.

\section{NNSNR:}

This is the difference between NNS - Rents from natural capital (excluding forestry)

\section{Rents from forestry:}

Rents from change in forestry are calculated as:

Rents $=$ Change in standing forest volume $\times$ unit price - cost of production Standing forest volume $=$ Standing stock of forest $\times$ average volume per hectare

Cost of production $=$ labour employed $\times$ average salaries

Forest volumes include the standing volume of both natural and planted forest in hectares. Standing volume in cubic meters is estimated by multiplying the standing stock of forest (in hectares) by average volume per hectare provided by the New Zealand Ministry of Primary Industries in the National Exotic Forest Description (NEFD) and Forest Owners Association (FOA) facts and figures reports. The cost of production is estimated from the product of a number of people employed in the forestry industry and real wage. Finally, market prices are determined by the average export price of all forest products from New Zealand. Data source: Labour and wages data from NZOYBs Stats NZ, estimated round wood removals from New Zealand forests from Ministry of Primary Industries, forest volume and volume per hectare from NFED and FOA.

\section{NNSF:}

It is given by the sum of Green Series and Rents from forestry.

\section{Genuine Savings (GS):}

Finally, GS is obtained from the sum of Super green series and investments human capital (i.e. education expenditures).

\section{Total Factor Productivity (TFP):}

The annual index of TFP is from Greasley and Madsen (2016, Equation 1) using their preferred TFP (BDL) variant. Trend growth of these data for each year 1950-2015 is extracted using a Kalman Filter and used to construct a measure of the value of 
technological progress. TFP series are compiled for GS, Green and Super Green series over $10,15,20$ and 30 years horizons. For sensitivity analysis, we used the present value of future changes in TFP of aforementioned series with $1.4 \%$ per year and $2.8 \%$ per year discount rates to value technological progress, where the discount rates are matched with those for consumption and GDP per capita.

\section{Net present values of consumption per capita, GDP per capita}

Net present values for the future changes in real consumption per capita, real GDP per capita and TFP data series are estimated following Ferreira et al. (2008) over 10, 15, 20 and 30 years horizons with a $2.8 \%$ per year discount rate.

Table A1: Summary statistics of key variables

\begin{tabular}{llllll}
\hline Statistic & N & Mean & St. Dev. & Min & Max \\
\hline PVGDP10 & 56 & $3,857.81$ & $2,309.92$ & $-1,258.79$ & $8,268.49$ \\
PVGDP15 & 51 & $5,366.83$ & $2,679.47$ & -724.12 & $11,418.59$ \\
PVGDP20 & 46 & $6,446.64$ & $2,867.35$ & $1,445.68$ & $12,234.16$ \\
PVGDP30 & 36 & $7,930.82$ & $2,710.34$ & $2,577.62$ & $12,919.38$ \\
PVC10 & 56 & $3,025.72$ & $1,596.44$ & 258.23 & $5,994.27$ \\
PVC15 & 51 & $4,107.84$ & $1,881.91$ & 827.29 & $8,472.81$ \\
PVC20 & 46 & $4,950.11$ & $2,085.52$ & $1,821.60$ & $9,134.51$ \\
PVC30 & 36 & $6,111.22$ & $1,914.30$ & $3,361.28$ & $9,656.93$ \\
NNSNRtp10 & 56 & $4,577.83$ & $1,125.61$ & $2,069.16$ & $6,955.17$ \\
NNSNRtp15 & 51 & $4,992.47$ & $1,059.53$ & $2,540.64$ & $7,870.10$ \\
NNSNRtp20 & 46 & $5,390.89$ & $1,095.28$ & $2,998.45$ & $8,598.33$ \\
NNSNRtp30 & 36 & $6,121.04$ & $1,185.19$ & $3,739.74$ & $9,496.08$ \\
NNSFtp10 & 56 & $5,520.64$ & $1,140.67$ & $3,343.64$ & $7,678.24$ \\
NNSFtp15 & 51 & $5,927.73$ & $1,049.77$ & $3,748.86$ & $8,298.27$ \\
NNSFtp20 & 46 & $6,228.14$ & 962.17 & $4,158.92$ & $8,851.96$ \\
NNSFtp 30 & 36 & $6,774.67$ & 911.06 & $4,911.85$ & $9,496.08$ \\
GStp10 & 56 & $6,812.08$ & $1,556.70$ & $4,661.02$ & $10,142.70$ \\
GStp15 & 51 & $7,115.40$ & $1,321.39$ & $5,145.97$ & $10,120.95$ \\
GStp20 & 46 & $7,328.77$ & $1,112.55$ & $5,556.03$ & $10,674.65$ \\
GStp30y & 36 & $7,727.93$ & 958.64 & $6,308.96$ & $9,925.12$ \\
\hline
\end{tabular}

Table A2: Summary of results with PV of change in GDP per capita at $2.8 \%$ discount rate

\begin{tabular}{llllll}
\hline $\mathbf{1}$ & $\mathbf{2}$ & $\mathbf{3}$ & $\mathbf{4}$ & $\mathbf{5}$ & $\mathbf{6}$ \\
Dependent & Independent & $\boldsymbol{\beta}_{\mathbf{0}}$ & $\boldsymbol{\beta}_{\mathbf{1}}$ & $\boldsymbol{\beta}_{\mathbf{1}}=\mathbf{1}\left(\boldsymbol{\chi}^{\mathbf{2})}\right.$ & $\boldsymbol{\beta}_{\mathbf{0}}=\mathbf{0}, \boldsymbol{\beta}_{\mathbf{1}}=\mathbf{1}\left(\boldsymbol{\chi}^{\mathbf{2}}\right)$ \\
\hline PVGDP10 & GNS & 1159.91 & $0.39 * *$ & $12.42 * * *$ & $121.36 * * *$ \\
PVGDP15 & GNS & 266.69 & $0.77 * * *$ & 0.77 & $13.54 * * *$ \\
PVGDP20 & GNS & 188.66 & $0.98 * * *$ & 0 & 0.04 \\
PVGDP30 & GNS & $5033.94 *$ & 0.48 & 1.38 & $19.51 * * *$ \\
PVGDP10 & NNS & $5490.67 * * *$ & -0.51 & $23.57 * * *$ & $28.68 * * *$ \\
PVGDP15 & NNS & $8406.79 * * *$ & $-1.01 * *$ & $23.04 * * *$ & $66.32 * * *$ \\
PVGDP20 & NNS & $10908.31 * * *$ & $-1.51 * * *$ & $33.28 * * *$ & $118.58 * * *$
\end{tabular}




\begin{tabular}{|c|c|}
\hline PVGDP30 & NNS \\
\hline PVGDP10 & NNSNR \\
\hline PVGDP15 & NNSNR \\
\hline PVGDP20 & NNSNR \\
\hline PVGDP30 & NNSNR \\
\hline PVGDP10 & NNSF \\
\hline PVGDP15 & NNSF \\
\hline PVGDP20 & NNSF \\
\hline PVGDP30 & NNSF \\
\hline PVGDP10 & GS \\
\hline PVGDP15 & GS \\
\hline PVGDP20 & GS \\
\hline PVGDP30 & GS \\
\hline PVGDP10 & NNSNRtp10 \\
\hline PVGDP15 & NNSNRtp10 \\
\hline PVGDP20 & NNSNRtp10 \\
\hline PVGDP30 & NNSNRtp10 \\
\hline PVGDP10 & NNSNRtp15 \\
\hline PVGDP15 & NNSNRtp15 \\
\hline PVGDP20 & NNSNRtp15 \\
\hline PVGDP30 & NNSNRtp15 \\
\hline PVGDP10 & NNSNRtp20 \\
\hline PVGDP15 & NNSNRtp20 \\
\hline PVGDP20 & NNSNRtp20 \\
\hline PVGDP30 & NNSNRtp20 \\
\hline PVGDP10 & NNSNRtp30 \\
\hline PVGDP15 & NNSNRtp30 \\
\hline PVGDP20 & NNSNRtp30 \\
\hline PVGDP30 & NNSNRtp30 \\
\hline PVGDP10 & NNSFtp10 \\
\hline PVGDP15 & NNSFtp10 \\
\hline PVGDP20 & NNSFtp10 \\
\hline PVGDP30 & NNSFtp10 \\
\hline PVGDP10 & NNSFtp15 \\
\hline PVGDP15 & NNSFtp15 \\
\hline PVGDP20 & NNSFtp15 \\
\hline PVGDP30 & NNSFtp15 \\
\hline PVGDP10 & NNSFtp20 \\
\hline PVGDP15 & NNSFtp20 \\
\hline PVGDP20 & NNSFtp20 \\
\hline PVGDP30 & NNSFtp20 \\
\hline PVGDP10 & NNSFtp30 \\
\hline PVGDP15 & NNSFtp30 \\
\hline PVGDP20 & NNSFtp30 \\
\hline PVGDP30 & NNSFtp30 \\
\hline PVGDP10 & GStp10 \\
\hline PVGDP15 & GStp10 \\
\hline PVGDP20 & GStp10 \\
\hline PVGDP30 & GStp10 \\
\hline PVGDP10 & GStp15 \\
\hline PVGDP15 & GStp15 \\
\hline
\end{tabular}

\begin{tabular}{|c|c|c|c|}
\hline $13310.59 * * *$ & $-1.81 * * *$ & $51.87 * * *$ & $243.57 * * *$ \\
\hline $5240.37 * * *$ & -0.46 & $20.95 * * *$ & $29.12 * * *$ \\
\hline $7834.33 * * *$ & $-0.87 * *$ & $19.02 * * *$ & $67.6 * * *$ \\
\hline $10181.9 * * *$ & $-1.35 * * *$ & $26.82 * * *$ & $115.65 * * *$ \\
\hline $12832.36 * * *$ & $-1.78 * * *$ & $48.55 * * *$ & $250.26 * * *$ \\
\hline $2170.64 *$ & 0.43 & $4.51 * *$ & 4.56 \\
\hline $3060.06 * *$ & $0.61 *$ & 1.23 & $20.22 * * *$ \\
\hline $3674.04 * *$ & $0.77 *$ & 0.3 & $47.73 * * *$ \\
\hline $6691.32 * * *$ & 0.36 & 1.54 & $100.13 * * *$ \\
\hline 1347.24 & $0.48 * *$ & $7.86 * * *$ & $29.34 * * *$ \\
\hline 1569.45 & $0.77 * * *$ & 0.89 & 2.32 \\
\hline 1691.59 & $1.01 * * *$ & 0 & $20.57 * * *$ \\
\hline $4390.24 * *$ & $0.81 * *$ & 0.23 & $68.17 * * *$ \\
\hline $5744.58 * * *$ & -0.41 & $26.65 * * *$ & $32.21 * * *$ \\
\hline $9342.73 * * *$ & $-0.9 * *$ & $28.77 * * *$ & $36.07 * * *$ \\
\hline $12934.35 * * *$ & $-1.5 * * *$ & $50.32 * * *$ & $84.87 * * *$ \\
\hline $16483.22 * * *$ & $-1.96 * * *$ & $143.93 * * *$ & $316.67 * * *$ \\
\hline $7027.27 * * *$ & $-0.66 * *$ & $29.15 * * *$ & $44.16 * * *$ \\
\hline $9253.38 * * *$ & $-0.78 * *$ & $26.77 * * *$ & $27.85 * * *$ \\
\hline $13250.89 * * *$ & $-1.39 * * *$ & $48.51 * * *$ & $66.18 * * *$ \\
\hline $17486.25 * * *$ & $-1.94 * * *$ & $178.12 * * *$ & $318 * * *$ \\
\hline $8207.62 * * *$ & $-0.89 * * *$ & $44.8 * * *$ & $86.49 * * *$ \\
\hline $10330.04 * * *$ & $-0.98 * * *$ & $35.84 * * *$ & $36.74 * * *$ \\
\hline $13399.47 * * *$ & $-1.29 * * *$ & $44.45 * * *$ & $52.5 * * *$ \\
\hline $18265.3 * * *$ & $-1.91 * * *$ & $185.02 * * *$ & $286.84 * * *$ \\
\hline $8426.9 * * *$ & $-0.93 * * *$ & $75.51 * * *$ & $245.47 * * *$ \\
\hline $9866.81 * * *$ & $-0.95 * * *$ & $74.46 * * *$ & $134.91 * * *$ \\
\hline $13209.82 * * *$ & $-1.28 * * *$ & $104.23 * * *$ & $112.52 * * *$ \\
\hline $19416.1 * * *$ & $-1.88 * * *$ & $164.61 * * *$ & $212.33 * * *$ \\
\hline 1859.23 & 0.36 & $5.54 * *$ & $34.97 * * *$ \\
\hline 3301.37 & 0.39 & $2.76 *$ & 2.76 \\
\hline $5406.33 * *$ & 0.2 & $2.87 *$ & $11.85 * * *$ \\
\hline $12404.27 * * *$ & -0.89 & $12.38 * * *$ & $55.99 * * *$ \\
\hline 1984.31 & 0.3 & $4.79 * *$ & $47.54 * * *$ \\
\hline 2888.19 & 0.42 & 2.62 & $4.87 *$ \\
\hline $5390.66 *$ & 0.18 & $3.11 *$ & $5.78 *$ \\
\hline $14336.73 * * *$ & $-1.15 * *$ & $17.41 * * *$ & $47.3 * * *$ \\
\hline $4838.48 * *$ & -0.23 & $12.05 * * *$ & $81.7 * * *$ \\
\hline $5173.75 *$ & -0.02 & $6.12 * *$ & $15.11 * * *$ \\
\hline 4959.93* & 0.24 & $2.89 *$ & 3.15 \\
\hline $14896.67 * * *$ & $-1.15 * *$ & $18.8 * * *$ & $38.18 * * *$ \\
\hline $9806.05 * * *$ & $-1.04 * * *$ & $44.22 * * *$ & $258.08 * * *$ \\
\hline $9709.12 * * *$ & $-0.83 * *$ & $30.41 * * *$ & $112.45 * * *$ \\
\hline $9450.98 * * *$ & -0.6 & $16.52 * * *$ & $32.27 * * *$ \\
\hline $14586.47 * * *$ & $-0.98 * *$ & $16.95 * * *$ & $24.09 * * *$ \\
\hline 647.09 & $0.47 * *$ & $7.62 * * *$ & $107.65 * * *$ \\
\hline 650.61 & $0.72 * *$ & 1.04 & $11.75 * * *$ \\
\hline 1167.29 & $0.84 * *$ & 0.18 & 0.37 \\
\hline 7337.48** & 0.1 & $3.19 *$ & $21.46 * * *$ \\
\hline-99.7 & $0.54 * *$ & $3.5 *$ & $113.56 * * *$ \\
\hline 63.41 & $0.75 * * *$ & 0.89 & $25.5 * * *$ \\
\hline
\end{tabular}




\begin{tabular}{llllll} 
PVGDP20 & GStp15 & 641.06 & $0.85 * *$ & 0.16 & 1.16 \\
PVGDP30 & GStp15 & $8891.73 * *$ & -0.15 & $4.83 * *$ & $14.01 * * *$ \\
PVGDP10 & GStp20 & 2358.25 & 0.14 & $7.78 * * *$ & $142.08 * * *$ \\
PVGDP15 & GStp20 & 1315.7 & 0.51 & 1.98 & $37.32 * * *$ \\
PVGDP20 & GStp20 & 128.72 & $0.86 * *$ & 0.14 & $4.94 *$ \\
PVGDP30 & GStp20 & $9415.51 * *$ & -0.21 & $5.54 * *$ & $9.6 * * *$ \\
PVGDP10 & GStp30 & $10325.09 * * *$ & $-0.98 * * *$ & $45.76 * * *$ & $370.4 * * *$ \\
PVGDP15 & GStp30 & $9176.58 * * *$ & $-0.66 * *$ & $26.2 * * *$ & $168.37 * * *$ \\
PVGDP20 & GStp30 & $6904.46 * *$ & -0.2 & $9.65 * * *$ & $51.47 * * *$ \\
PVGDP30 & GStp30 & $8895.02 * *$ & -0.12 & $5.39 * *$ & $5.59 *$ \\
\hline
\end{tabular}

NOTES: See the notes of Table 2 (main text) for the explanation of null and alternative hypotheses and the levels of significance.

Table A3: Summary of results with PV of change in consumption per capita at $2.8 \%$ discount rate

\begin{tabular}{|c|c|c|c|c|c|}
\hline $\begin{array}{l}1 \\
\text { Dependent }\end{array}$ & $\begin{array}{l}2 \\
\text { Independent }\end{array}$ & $\begin{array}{l}3 \\
\text { BO }\end{array}$ & $\begin{array}{l}4 \\
\text { B1 }\end{array}$ & $\begin{array}{l}5 \\
B 1=1\left(X^{2}\right)\end{array}$ & $\begin{array}{l}6 \\
B 0=0, B 1=1\end{array}$ \\
\hline PVC10 & GNS & -604.2 & $0.52 * * *$ & $21.36 * * *$ & $513.75 * * *$ \\
\hline PVC15 & GNS & -1036.77 & $0.78 * * *$ & 1.81 & $130.71 * * *$ \\
\hline PVC20 & GNS & -1015.26 & $0.94 * * *$ & 0.08 & $29.05 * * *$ \\
\hline PVC30 & GNS & 2549.31 & $0.59 *$ & 1.85 & 1.95 \\
\hline PVC10 & NNS & $2513.28 * * *$ & 0.16 & $14.53 * * *$ & $14.99 * * *$ \\
\hline PVC15 & NNS & $5060.12 * * *$ & -0.32 & $18.29 * * *$ & $35.68 * * *$ \\
\hline PVC20 & NNS & $7050 * * *$ & $-0.71 * *$ & $25.19 * * *$ & $70.72 * * *$ \\
\hline PVC30 & NNS & $9277.66 * * *$ & $-1.07 * * *$ & $47.03 * * *$ & $176.22 * * *$ \\
\hline PVC10 & NNSNR & $2429.98 * * *$ & 0.2 & $12.82 * * *$ & $12.86 * * *$ \\
\hline PVC15 & NNSNR & $4720.45 * * *$ & -0.22 & $15.17 * * *$ & $38.44 * * *$ \\
\hline PVC20 & NNSNR & $6551.38 * * *$ & -0.58 & $20.24 * * *$ & $72.43 * * *$ \\
\hline PVC30 & NNSNR & $8972.72 * * *$ & $-1.04 * * *$ & $44.21 * * *$ & $187.52 * * *$ \\
\hline PVC10 & NNSF & 390.07 & $0.67 * * *$ & $3.9 * *$ & $26.72 * * *$ \\
\hline PVC15 & NNSF & 1087.59 & $0.8 * * *$ & 0.77 & 2.86 \\
\hline PVC20 & NNSF & 1823.81 & $0.87 * * *$ & 0.21 & $22.63 * * *$ \\
\hline PVC30 & NNSF & $4148.65 * * *$ & 0.57 & 1.47 & $76.41 * * *$ \\
\hline PVC10 & GS & 26.67 & $0.57 * * *$ & $14.71 * * *$ & $170.09 * * *$ \\
\hline PVC15 & GS & 265.61 & $0.78 * * *$ & 2.11 & $17.39 * * *$ \\
\hline PVC20 & GS & 560.44 & $0.93 * * *$ & 0.11 & 0.99 \\
\hline PVC30 & GS & $2659.05 * *$ & $0.79 * * *$ & 0.63 & $37.37 * * *$ \\
\hline PVC10 & NNSNRtp10 & $2422.8 * * *$ & 0.13 & $20.42 * * *$ & $72.84 * * *$ \\
\hline PVC15 & NNSNRtp10 & $5542.57 * * *$ & -0.33 & $25.8 * * *$ & $27.08 * * *$ \\
\hline PVC20 & NNSNRtp10 & $8309.76 * * *$ & $-0.78 * * *$ & $39.97 * * *$ & $44.61 * * *$ \\
\hline PVC30 & NNSNRtp10 & $11512 * * *$ & $-1.24 * * *$ & $120.18 * * *$ & $180.67 * * *$ \\
\hline PVC10 & NNSNRtp15 & $3593.8 * * *$ & -0.15 & $32.19 * * *$ & $135.45 * * *$ \\
\hline PVC15 & NNSNRtp15 & $5412.61 * * *$ & -0.26 & $25.26 * * *$ & $36.55 * * *$ \\
\hline PVC20 & NNSNRtp15 & $8444.71 * * *$ & $-0.71 * *$ & $39.79 * * *$ & $39.81 * * *$ \\
\hline PVC30 & NNSNRtp15 & $12176.61 * * *$ & $-1.23 * * *$ & $143.1 * * *$ & $173.12 * * *$ \\
\hline PVC10 & NNSNRtp20 & $4364.52 * * *$ & $-0.34 *$ & $57.2 * * *$ & $277.1 * * *$ \\
\hline PVC15 & NNSNRtp20 & $6261.8 * * *$ & $-0.45 *$ & $39.94 * * *$ & $79.73 * * *$ \\
\hline PVC20 & NNSNRtp20 & $8442.9 * * *$ & $-0.65 * *$ & $37.27 * * *$ & $39.54 * * *$ \\
\hline
\end{tabular}




\begin{tabular}{|c|c|c|c|c|c|}
\hline PVC30 & NNSNRtp20 & $12643.48 * * *$ & $-1.21 * * *$ & $145.39 * * *$ & $156.31 * * *$ \\
\hline PVC10 & NNSNRtp30 & $4596.72 * * *$ & $-0.41 * * *$ & $106.6 * * *$ & $740.38 * * *$ \\
\hline PVC15 & NNSNRtp30 & $5945.6 * * *$ & $-0.46 * * *$ & $108.08 * * *$ & $440.3 * * *$ \\
\hline PVC20 & NNSNRtp30 & $8085.82 * * *$ & $-0.65 * * *$ & $105.28 * * *$ & $222.2 * * *$ \\
\hline PVC30 & NNSNRtp30 & $13278.44 * * *$ & $-1.17 * * *$ & $129.46 * * *$ & $129.46 * * *$ \\
\hline PVC10 & NNSFtp10 & -619.44 & $0.66 * * *$ & $4.09 * *$ & $176.82 * * *$ \\
\hline PVC15 & NNSFtp10 & 378.08 & $0.7 * * *$ & 1.54 & $26.57 * * *$ \\
\hline PVC20 & NNSFtp10 & 2160.01 & 0.54 & 1.9 & 2.42 \\
\hline PVC30 & NNSFtp10 & $7430.23 * * *$ & -0.26 & $10.37 * * *$ & $21.89 * * *$ \\
\hline PVC10 & NNSFtp15 & -181.58 & $0.51 * *$ & $6.5 * *$ & $244.9 * * *$ \\
\hline PVC15 & NNSFtp15 & -63.28 & $0.7 * * *$ & 1.58 & $56.84 * * *$ \\
\hline PVC20 & NNSFtp15 & 1941.32 & 0.52 & 2.11 & $9.1 * *$ \\
\hline PVC30 & NNSFtp15 & $8596.66 * * *$ & -0.44 & $14.36 * * *$ & $17.05 * * *$ \\
\hline PVC10 & NNSFtp20 & 1652.35 & 0.14 & $16.9 * * *$ & $361.42 * * *$ \\
\hline PVC15 & NNSFtp20 & 1507.92 & 0.37 & $5.54 * *$ & $95.22 * * *$ \\
\hline PVC20 & NNSFtp20 & 1563.45 & $0.54 *$ & 2.08 & $20.11 * * *$ \\
\hline PVC30 & NNSFtp20 & $8866.13 * * *$ & -0.45 & $15.57 * * *$ & $15.6 * * *$ \\
\hline PVC10 & NNSFtp30 & $4846.26 * * *$ & $-0.4 * *$ & $56.65 * * *$ & $830.46 * * *$ \\
\hline PVC15 & NNSFtp30 & $4514.23 * * *$ & -0.2 & $33.98 * * *$ & $419.71 * * *$ \\
\hline PVC20 & NNSFtp30 & $4712.43 * *$ & -0.09 & $18.38 * * *$ & $156.4 * * *$ \\
\hline PVC30 & NNSFtp30 & $8459.86 * * *$ & -0.35 & $14.36 * * *$ & $18.68 * * *$ \\
\hline PVC10 & GStp10 & -1062.18 & $0.6 * * *$ & $12.49 * * *$ & $482.82 * * *$ \\
\hline PVC15 & GStp10 & -1102.37 & $0.8 * * *$ & 1.41 & $121.19 * * *$ \\
\hline PVC20 & GStp10 & -671.58 & $0.9 * * *$ & 0.17 & $23.32 * * *$ \\
\hline PVC30 & GStp10 & $3841.94 *$ & 0.38 & $3.13 *$ & 3.32 \\
\hline PVC10 & GStp15 & -1186.07 & $0.56 * * *$ & $9.32 * * *$ & $535.77 * * *$ \\
\hline PVC15 & GStp15 & -1675.65 & $0.81 * * *$ & 1.26 & $190.57 * * *$ \\
\hline PVC20 & GStp15 & -1300.42 & $0.91 * * *$ & 0.12 & $48.42 * * *$ \\
\hline PVC30 & GStp15 & $4562.95 *$ & 0.24 & $4.33 * *$ & $6.13 * *$ \\
\hline PVC10 & GStp20 & 398.15 & 0.29 & $16.2 * * *$ & $628.4 * * *$ \\
\hline PVC15 & GStp20 & -931.99 & $0.65 * * *$ & 2.68 & $222.82 * * *$ \\
\hline PVC20 & GStp20 & -1749.93 & $0.91 * * *$ & 0.12 & $76.89 * * *$ \\
\hline PVC30 & GStp20 & $4737.37 *$ & 0.2 & $4.91 * *$ & $12.68 * * *$ \\
\hline PVC10 & GStp30 & $5143.18 * * *$ & $-0.39 * *$ & $62.11 * * *$ & $1192.26 * * *$ \\
\hline PVC15 & GStp30 & $4027.62 * *$ & -0.12 & $31.73 * * *$ & $634.45 * * *$ \\
\hline PVC20 & GStp30 & 3073.86 & 0.13 & $12.93 * * *$ & $267.29 * * *$ \\
\hline PVC30 & GStp30 & 4291.55 & 0.24 & $5.05 * *$ & $30.35 * * *$ \\
\hline
\end{tabular}

NOTES: See the notes of table 2 notes for the explanation of null and alternative hypotheses and the levels of significance. 